\title{
MENTALIDAD, CULTURA Y REPRESENTACIÓN DEL PODER DE LA NOBLEZA CALATRAVA EN LA CASTILLA DEL SIGLO XV
}

\author{
ENRIQUE RODRÍGUEZ-PICAVEA MATILLA \\ OLGA PÉREZ MONZÓN \\ Universidad Autónoma de Madrid
}

RESUMEN: El artículo analiza las características de la nobleza calatrava a través de su mentalidad, cultura y exbibición de poder. La cuestión, que había sido estudiada para el caso de la nobleza laica, no contaba con un análisis desde la particular perspectiva de la orden calatrava. Para lograr este objetivo se ha combinado el análisis de las fuentes cronísticas y la documentación archivística con el de los restos materiales y los testimonios iconográficos. El resultado del estudio es que los calatravos, a pesar de los condicionantes de su pertenencia a una institución religiosa, asumieron la mentalidad y la cultura nobiliarias, practicaron un ocio aristocrático y desplegaron una representación del poder similar a la desarrollada por la nobleza laica.

PALABRAS Clave: Nobleza, poder, Orden de Calatrava, iconografía, representación, Castilla, siglo XV.

ABSTRACT: The article tries to analyze the characteristics of the Calatravan nobility through its mentality, culture and exhibition of power. The question, that had been studied for the case of the lay nobility, did not count on an analysis from the Calatravan perspective individual. In order to obtain this objective it has been used chronicas, archive's documentation with artistics testimonies. The result of the study is that the Calatravans assumed the nobiliary mentality and the culture, performed an aristocratic leisure and unfolded a representation of the power similar to the developed one by the lay nobility.

KEY WORDS: Nobility, power, Order of Calatrava, iconography, representation, Castile, fifteenth century. 
Al iniciarse el siglo XV la Orden de Calatrava se encontraba inmersa en un proceso de aristocratización que había comenzado como poco a finales del siglo XIII. El maestrazgo de Gonzalo Núñez de Guzmán (1385-1404) supuso un impulso decisivo en ese proceso y en la secularización de los caballeros calatravos. El proceso se acentuó particularmente durante los maestrazgos de Luis González de Guzmán (1414-1443) y Pedro Girón (1445-1466), conociendo sus últimos retoques en tiempos de los Reyes Católicos y en las primeras décadas del siglo XVI. De tal suerte que durante esos años decisivos en la evolución de la institución calatrava la secularización se materializa en la atenuación o incumplimiento de los votos monásticos y los estatutos religiosos, mientras que la aristocratización se manifiesta a través de la instrumentalización de la Orden por parte de la nobleza. Los grandes beneficiarios de esta situación son los linajes nobiliarios que a lo largo de la decimoquinta centuria controlan las principales jerarquías calatravas: Guzmán, Padilla y Girón. Estas tres familias serán las únicas que, con las excepciones de las coyunturales imposiciones regias, conseguirán acceder al maestrazgo calatravo en el siglo XV, contando cada una de ellas con dos representantes ${ }^{1}$. Así, a los ya citados, hay que añadir los nombres de Fernando de Padilla (electo en 1443), Rodrigo Téllez Girón (14661482) y García López de Padilla (1482-1489).

Estos linajes, y otros de menor importancia en el seno de la institución calatrava, patrimonializaron bienes y rentas de la Orden en su propio beneficio, disfrutaron de cargos políticos y desplegaron unas estrategias familiares que en nada les diferenciaban del resto de la nobleza no integrada en una institución religiosa ${ }^{2}$. Con todo, la nobleza calatrava tenía en teoría que someterse a unos condicionantes desconocidos para la nobleza estrictamente laica como la obligación de cumplir los votos, la regla y los estatutos; proceder de matrimonio legítimo o en su defecto obtener la dispensa papal; esperar a la edad adecuada

1 Rodríguez-Picavea Matilla, E.: «Linaje y poder en la Castilla Trastámara. El ejemplo de la Orden de Calatrava»: Anuario de Estudios Medievales, 35/1 (2005) 91-130.

2 La proliferación de trabajos sobre la nobleza castellana bajomedieval haría interminable la lista de referencias, razón por la cual remitiremos a varios balances historiográficos sobre el tema que nos puedan guiar en esta cuestión. Vid. Quintanilla Raso, M.C.: «Nobleza y señoríos en Castilla durante la Baja Edad Media. Aportaciones de la historiografía reciente»: Anuario de Estudios Medievales, 14 (1984) 613-639; «Historiografía de una élite de poder: la nobleza castellana bajomedieval»: Hispania, 175 (1990) 719-736; y «El protagonismo nobiliario en la Castilla bajomedieval. Una revisión historiográfica (1984-1997)»: Medievalismo. Boletín de la Sociedad Española de Estudios Medievales, 7 (1997) 187-234. Con posterioridad a esta última fecha, pueden verse, entre otras, las obras de CABRera SÁNCHEZ, M.: Nobleza, oligarquía y poder en Córdoba al final de la Edad Media, Córdoba, 1998; Gibello Bravo, V.M.: La imagen de la nobleza castellana en la Baja Edad Media, Badajoz, 1999; SÁnChez PRieto, A.B.: La casa de Mendoza hasta el tercer duque del Infantado (13501531): el ejercicio y alcance del poder señorial en la Castilla bajomedieval, Madrid, 2001; y el volumen colectivo La nobleza peninsular en la Edad Media. VI Congreso de Estudios Medievales, Fundación Sánchez Albornoz, Ávila, 1999. Con anterioridad, es interesante recordar, por su carácter más general, la visión ofrecida por I. BeCeiro PitA y R. CóRdoba DE LA Llave, Parentesco, poder y mentalidad. La nobleza castellana. Siglos XII-XV, Madrid, 1990. 
para recibir primero el hábito y después una encomienda; una mayor instrumentalización y mediatización por parte de la monarquía; y cumplir las obligaciones económicas con la Orden, que implicaban también el mantenimiento en buen estado del patrimonio comendatario.

En contrapartida, conviene recordar que estas prescripciones se incumplían en no pocas ocasiones y que además las rentas a las que podían aspirar los caballeros calatravos si lograban acceder a las más altas jerarquías podían superar con creces el nivel de ingresos alcanzados por muchos señores laicos ${ }^{3}$. Todas estas circunstancias permitieron a los freires calatravos unas pautas de comportamiento que traducían una mentalidad propia de la nobleza laica, lo que posibilitó que llevaran a cabo proyectos de representación del poder que en ocasiones superaron los desplegados por otros nobles.

En buena lógica con todo lo que venimos diciendo hasta ahora, los miembros de las órdenes militares ${ }^{4}$, en la medida en que pertenecían a linajes nobiliarios, fueron configurando una ideología propia, unos valores, un modo de vida y unas actitudes que les distinguían del resto de la sociedad's. Entramos así en el interesante terreno de la historia de las mentalidades. El ideal nobiliario comenzaba a impregnar toda la vida social y naturalmente las órdenes militares no fueron ajenas a ello.

De esta suerte, los freires calatravos asumieron como propios los comportamientos de la mentalidad nobiliaria como son la práctica de un ocio aristocrático, la aceptación de los valores caballerescos, el consumo de obras literarias, la sustitución del castillo por el palacio, la elevación de capillas funerarias, el

3 Rodríguez-Picavea Matilla, E.: «La nobleza y la Orden de Calatrava en tiempos de Juan II de Castilla»: As Orden Militares e de Cavalaria na Construçao do Mundo Ocidental. Actas do IV Encontro sobre Ordens Militares, Lisboa, 2005, 585-620.

${ }^{4}$ Sobre la historiografía medieval de las órdenes militares hispánicas vid. LOMAX, D.: Las Órdenes Militares en la Peninsula durante la Edad Media, Salamanca, 1976; Ayala Martínez, C. y otros, «Las Ordenes Militares en la Edad Media peninsular. Historiografía»: Medievalismo. Boletín de la Sociedad Española de Estudios Medievales, 2 (1992) 119-169 y 3 (1993), 87-144; JOSSERAND, Ph.: «L'historiographie des Ordres Militaires dans les royaumes de Castille et de León. Bilan et perspectives de la recherche en histoire médiévale»: Atalaya. Revue française d'études médiévales hispaniques, 9 (1998) 5-44; Ayala MarTínez, C. «Las órdenes militares hispánicas en la Edad Media. Aproximación bibliográfica»: Fr. Javier Campos, ed.: Estudios sobre las Órdenes Militares. Lux Hispaniarum, Madrid, 1999, 425-457; LADERO QueSADA, Miguel Ángel, «La investigación sobre Órdenes Militares en la Edad Media hispánica durante los últimos decenios: Corona de Castilla y León»: R. Izquierdo y F. Ruiz, eds.: Las Órdenes militares en la Península Ibérica, I. Edad Media, Cuenca, 2000, 931; Ayala Martínez, C. y BARQuero GoÑI, C.: «Historiografía hispánica y órdenes militares en la Edad Media, 1993-2003»: Medievalismo. Boletín de la Sociedad Española de Estudios Medievales, 12 (2002) 101-161.

5 Sin embargo, conviene tener muy presente el contraste existente entre la imagen ideal de la nobleza, en la que destacaban la fama, la generosidad, el valor, el honor, el servicio y la honra, y la realidad de un comportamiento cotidiano en el que no faltaban el miedo, la avaricia, el deservicio y la violencia. Sobre todo ello vid. el libro ya citado de Gibello BRAvo, V.M.: La imagen de la nobleza castellana en la Baja Edad Media. 
«mecenazgo» religioso y cultural y la promoción de obras artísticas ${ }^{6}$ que reflejan una particular visión del mundo y una idea de la fama y la trascendencia tan alejadas de los ideales de una institución religiosa.

En este contexto, las instituciones religioso-militares fueron utilizadas también para desarrollar todo un sistema de representaciones, imágenes y conceptos como instrumento al servicio de los intereses nobiliarios de legitimación socio-política y proyección externa de su creciente poder ${ }^{7}$. Entonces entran en juego los mecanismos de representación y creación literaria y artística. Los miembros de las órdenes militares intentan imponer su mentalidad social mediante las obras que ellos mismos han encargado y con las que se identifican plenamente ${ }^{8}$.

\section{Mentalidad, OCiO Y CUltura NOBiLiaRia}

La práctica de un ocio aristocrático es habitual entre los caballeros calatravos y en nada se diferencian en este aspecto de la nobleza, participando en las actividades propias de su clase como fiestas, banquetes, juegos y presumiblemente torneos, además de ejercitarse en las artes cinegéticas aristocráticas, donde a veces no es fácil diferenciar el componente lúdico de la preparación física adecuada para la actividad militar ${ }^{9}$. Según el maestre Luis González de Guzmán, muchos reyes y señores solían yr a caça o oyr los libros ystoriales ${ }^{10}$ o poetas, o jugar axedres o tablas o sus semejantes juegos. El maestre y los caballeros de su Orden debieron ser también asiduos practicantes de estas actividades.

Tales inquietudes suponían el marco oportuno para la manifestación de los valores caballerescos que, por otra parte, encontraban un cauce adecuado de materialización en la formación de facciones nobiliarias en el seno de la propia Orden. El enfrentamiento más destacado entre los linajes Guzmán y Padilla por el control de la institución calatrava tuvo lugar en la batalla del Campo de

${ }^{6}$ Vid. Quintanilla Raso, M.C.: «La renovación nobiliaria en la Castilla bajomedieval. Entre el debate y la propuesta»: La nobleza peninsular en la Edad Media. VI Congreso de Estudios Medievales, Ávila, 1999, 255-295, pp. 293-295.

7 Se ha ocupado de la propaganda legitimadora del poder nobiliario QUINTANILLA RAsO, M.C.: «La nobleza»: Nieto SORIA, J.M. (dir.), Orígenes de la Monarquía Hispánica: Propaganda y legitimación (ca. 1400-1520), Madrid, 1999, 63-103. 204.

8 Quintanilla Raso, «El protagonismo nobiliario en la Castilla bajomedieval», pp. 203-

9 Así lo expresa la Ley XX del Título V de la II Partida de Alfonso X el Sabio referida a la figura del rey. La cita es extensible a la nobleza.

10 Según Paz y Melia el Amadís y la Conquista de Troya estaban entre las preferencias literarias del maestre Guzmán. Sin embargo, el rabino Moisés Arragel, en los comentarios incluidos en la Biblia de Alba, consideraba que ambas obras, muy difundidas en la época, eran de poco provecho. Vid. PaZ y Melia, A.: «La Biblia puesta en romance por rabí Mosé Arraguel de Guadalfajara»: Homenaje a Menéndez Pelayo, Madrid, 1899, vol. II, 5-93, pp. 6 y 29. 
Barajas (1442), personalizado en las figuras del comendador mayor Juan Ramírez de Guzmán y el clavero Fernando de Padilla:

... la qual fue por ambas parte ásperamente ferida, en la qual el Comendador mayor fué presso, é dos hermanos suyos é su hijo, é fueron muertos quatro sobrinos suyos, é muchos otros presos, é murieron muchos caballos de ambas partes, é de la parte del Clavero fueron algunos muertos, aunque no hombres de faccion, é otros fueron feridos ${ }^{11}$.

A pesar de la victoria del bando que apoyaba al clavero Padilla, la disputa no terminó, incluso se prolongó tras la muerte accidental de este último ${ }^{12}$. Su hermano y sucesor en la clavería, García López de Padilla, retomó el mando de los intereses del linaje en el interior de la Orden frente a los que representaba Juan Ramírez de Guzmán.

El acceso al maestrazgo de Pedro Girón en 1445 propició la formación de otras dos facciones en el seno de la institución calatrava. La mayoritaria, y adepta al nuevo maestre, tenía el apoyo del clavero Padilla, el voto de 22 comendadores y otros muchos freires clérigos y legos. La encabezada por Juan Ramírez de Guzmán estaba respaldada por tres comendadores, cuatro caballeros y 14 clérigos, además tenía el control sobre la tierra de Zorita, las villas de Osuna y Martos y otras plazas andaluzas ${ }^{13}$. El conflicto se solucionó mediante un acuerdo en 1448, pero las facciones subsistieron en el interior de la Orden. Esta circunstancia explicará la posterior oposición de Fernán Gómez de Guzmán, hijo de Juan Ramírez de Guzmán y sucesor de su padre al frente de la encomienda mayor, al nombramiento de Rodrigo Téllez Girón como maestre de Calatrava a la muerte de su progenitor Pedro Girón en 1466. La idea la expresa con acierto Emilio Cabrera, que indica también la impotencia del comendador mayor para impedirlo, dado el control que sobre la Orden y su sobrino ejercía el marqués de Villena, Juan Pacheco. La tensión se prolongó por el control de la estratégica fortaleza de Belmez, perteneciente a la encomienda mayor, pero que había mandado ocupar Pedro Girón en 1464 y no pudo sitiar Fernán Gómez de Guzmán hasta la muerte de Juan Pacheco. A partir de entonces, el comendador mayor encontró un cauce adecuado para su aspiración al maestrazgo en el apoyo a la causa de Isabel y Fernando, situándose así en el bando contrario al del maestre Rodrigo Téllez Girón que defendía la candida-

\footnotetext{
11 Pérez de Guzmán, F.: Crónica de Juan II: Crónicas de los Reyes de Castilla, II, Biblioteca de Autores Españoles, colección ordenada por Rosell, C.: Madrid, 1953, tomo 68, 277-695, p. 609.

12 Pérez de GuZMán, Crónica de Juan II, pp. 610-613.

13 Pérez de Guzmán, Crónica de Juan II, p. 639; RAdes y Andrada, F. DE, Chronica de las tres Ordenes y Caballerías de Santiago, Calatrava y Alcántara, Toledo, 1572, ed. facs.: Barcelona, 1980 y Valencia, 1994, Chronica de Calatrava, fols. 72r-73r; O'Callaghan, J.: «Don Pedro Girón, Master of the Order of Calatrava, 1445-1446»: Hispania, 21 (1961) 342-392, pp. 354-356; SOLANO RuIZ, E.: La Orden de Calatrava en el siglo XV. Los señoríos castellanos de la Orden al fin de la Edad Media, Sevilla, 1978, pp. 87-88.
} 
tura de Juana la Beltraneja. Esta pretensión de ocupar el maestrazgo fue, según el profesor Cabrera, «una de las razones principales de su violenta muerte. Lo demás fue sólo el pretexto» ${ }^{14}$.

Entre los maestres calatravos el componente aristocrático se subraya con el mantenimiento de cortes paralelas a las regias. Pedro Girón ejemplifica claramente esta realidad al disponer, entre otros servidores, de canciller, mayordomo, maestresala, secretario, aposentadores, alguacil, despensero, copero, oficial de la cancillería, reposteros de plata, contador, espingarderos, montero, sirvientes de cámara, más de una decena de pajes, cocinero, ayudantes de cocina, mozo de espuelas, repostero, trompetas, platero, cazador, potrero, mozo de caballos, mozo de cámara y lombardero, además de esclavos.

Precisamente en el testamento de este maestre calatravo, se menciona entre los beneficiarios a Johan de Lugo, mi caçador, agraciado con 10.000 maravedís ${ }^{15}$. Contamos además con testimonios anteriores sobre la práctica de la caza en su dimensión nobiliaria por parte de caballeros calatravos. El más temprano se remonta a la primera mitad del siglo XIV, cuando don Juan Manuel ensalza en el capítulo II de su Libro de la Caza las cualidades cinegéticas de Ramiro Lorenzo Gallinato, clavero de Calatrava:

... saben mucho de caça de açores, et sennalada mente a Remir Llorençio, que es agora clauero de Calatraua, et a Pero Ximenes, fijo de Iohan Garcia de Alcabdote, que son los mejores caçadores que el nunca vio, et que mas saben desta caça, nin que mejores açores fagan. Et dize don Iohan que lo que estos omnes fazen en caça de açores, que mas lo tiene el por marauilla que por sabiduria de caça ${ }^{16}$.

Un siglo después, el maestre Luis González de Guzmán aparece representado con un halcón en la mano, especie animal utilizada en el arte de la cetrería, que era la práctica cinegética nobiliaria por antonomasia ${ }^{17}$.

En relación a las preferencias literarias por parte de los caballeros calatravos no tenemos datos precisos para el siglo XV. A partir de 1452 se documenta en el convento de Calatrava una caja o armario con llave para guardar libros que el prior, en ausencia del sacristán, distribuía entre los que lo solicitasen en tem-

\footnotetext{
14 CABrera, E.: «El acceso a la dignidad de maestre y las divisiones internas de las Órdenes Militares durante el siglo XV»: IZQuierdo BENito, R. y Ruiz GómeZ, F. (eds.), Las Órdenes militares en la Península Ibérica. I: Edad Media, Cuenca, 2000, 281-306, pp. 301-302, nota 40.

15 Casado Quintanilla, B.: Corona de Castilla: Documentos de la Orden de Calatrava expedidos durante los tres últimos maestrazgos (1445-1489). Estudio diplomático, Madrid, 1997, p. 302.

16 Don Juan Manuel, Libro de la Caza: Don JuAn MAnuel, Obras completas, edición, prólogo y notas de José Manuel Blecua, 2 vols.: Madrid, 1981, vol. I, p. 527.

17 La miniatura del maestre se encuentra en Biblia de la Casa de Alba, fol. 1v (Fundación Casa de Alba, Madrid). Más ejemplos relativos a la práctica cinegética de caballeros de otras órdenes militares en Ayala MarTíneZ, C. DE, Las Órdenes militares hispánicas en la Edad Media (siglos XIIXV), Madrid, 2003, pp. 390-391.
} 
pore lectionis ${ }^{18}$. Con el tiempo, se construyó una biblioteca organizada en dos alturas. El depósito de libros ocupaba la planta alta y la sala de lectura, la baja. Los freires clérigos del convento, especialmente el maestro de novicios y sus discípulos, eran sus principales usuarios al estar obligados a aprender gramática y otras ciencias. Ya desde la Definiciones de 1437, y posteriormente en las de 1448 y 1462, se disponía la presencia de un maestro de novicios en el convento de Calatrava con salario a cargo del maestre ${ }^{19}$. Sin embargo, en la visita realizada en 1468, el abad Guillermo II de Morimond no encontró a ninguno desempeñando ese cargo y estableció que el maestre designara para instruir a los freires in primitivis scientiarum a un maestro de gramática ${ }^{20}$. Posteriormente, a partir de finales del siglo $\mathrm{XV}$, el prior del convento calatravo nombraría además a un lector de teología y artes para que enseñara a los freires esas disciplinas y otras con cargo a un juro de 25.000 maravedís que había dejado el sacristán frey Bartolomé ${ }^{21}$.

De forma eventual, los libros del sacro convento podían ser demandados por caballeros calatravos. A este fin, funcionaba un sistema de préstamo que permitía sacar libros del convento y obligaba al beneficiario del mismo a devolver otro libro por cada uno de los que se hubiesen perdido. Cuando se hizo un inventario en 1526, el comendador de Daimiel Gonzalo del Arroyo tenía 20 libros prestados en su casa y el bachiller frey Pedro Piñar seis. A principios del siglo XVI, los libros se habían atado con cadenas para evitar su desaparición ${ }^{22}$.

La primera relación de libros conocida data de $1495^{23}$. Los manuscritos dominaban sobre los libros impresos o de molde, la escritura en latín convivía con la lengua romance y todos se guardaban en un armario bajo llave en poder del sacristán. La biblioteca tenía una clara orientación religiosa. Había varias biblias, libros de evangelios y epístolas, un salterio glosado, homilías, dos epís-

${ }_{18}$ Et quia nil adeo inimicatur religiosis sicut ocium et sacrista continue non residat in conventu, statuimus et ordinamus quod libri conventus pro studio ponantur in aliqua caxa vel armario cuius alteram clavem prior teneat ut possit tempore lectionis volentibus studere distribuere. Disposición contenida en las Definiciones otorgadas por el abad Juan VII de Morimond en 1452. Vid. Archivo Histórico Nacional, Ordenes Militares (en adelante AHN, OO.MM.), sign. 1348 c, Registro de Escrituras de la Orden de Calatrava, VIII, fol. 98r. La disposición fue repetida en las Definiciones del abad Guillermo II de Morimond de 1468. Vid. AHN, Códices, sign. 807B. Publ. O'Callaghan, J.: «Difiniciones of the Order of Calatrava enacted by Abbot William II of Morimond, April 2, 1468»: Traditio, 14 (1958), 231-268, p. 239.

19 FERnÁndeZ IZQUIERdo, F.: La Orden de Calatrava en el siglo XVI. Infraestructura institucional. Sociología y prosopografía de sus caballeros, Madrid, 1992, p. 77.

20 O'Callaghan, «Difiniciones of the Order of Calatrava enacted by Abbot William II of Morimond, April 2, 1468», p. 244.

21 FERNÁNDEZ IZQUIERDO, La Orden de Calatrava en el siglo XVI, pp. 77-78.

22 Casado Quintanilla, B.: «La biblioteca del Sacro Convento de Calatrava»: Espacio, Tiempo y Forma. Historia Medieval, 2 (1989) 65-120, pp. 76-78.

${ }_{23}$ AHN, OO.MM.: leg. 6109, fols. 179v-180. Se conocen también inventarios de 1500 y 1519. Vid. ZAPATA ALARCÓN, J.: «La biblioteca de Calatrava la Nueva: 1526-1803» LóPEZ-SALAZAR, J. (coord.), Las Órdenes militares en la Península Ibérica. II: Edad Moderna, Cuenca, 2000, 1389-1405, pp. 1389-1392. 
tolas de San Pablo, tres reglas de San Benito, una regla de la Orden de San Juan, las Definiciones del Cister, un breviario, biografías de San Benito o San Bernardo y textos diversos muy difundidos en los últimos momentos del gótico. Significativa es la presencia de los Moralia de Job, uno de los libros más leídos del medievo, y un Flor Santorum istoriado que podríamos interpretar como un cuaderno de grabados en la línea de las series de Ars moriendi o de las Biblias Pauperum donde las imágenes iban acompañadas de un texto explicativo. Los dos libros de la Vita Christi corresponden a la profusión de textos en el tardogótico sobre la ejemplaridad de la vida de la Virgen y Cristo. La anotación en romance incluida en el documento, apunta a que se trata del libro de Eixemenis, ya que el de Ludovico de Sajonia no se tradujo al castellano hasta $1502^{24}$. Como literatura ejemplar, hallamos un Libro del tesoro, identificado con Li Livres dou Tresor de Brunetto Latini (h. 1268) ${ }^{25}$, y la Visión Deletable de Alfonso de la Torre (h.1430). El polígrafo Ramón Llul está presente con un ejemplar de la Doctrina Pueril y Alfonso Fernández Madrigal con su Confesión.

El convento calatravo, además, custodiaba un buen elenco de textos clásicos - Séneca, Aristóteles, Tito Livio, poesía -Coplas del Marqués de Santillana, libros de otras religiones - el Corán-, crónicas - Primera parte de la General Estoria, Segunda Parte de la General Estoria, Crónicas Romanas, un libro de lo que acontesció en Roma en tiempos de Julio Cesar y otros tratados,...-, literatura antijudía - Quitaciones de Nicolás de Lyra contra los judíos-, textos profanos - Panfilus o De Amore, libro de axedrez-, filosóficos - Tratado del doctor Pedro Díaz cuando adolesció el Marqués de Santillana ${ }^{26}$ - y literatura especular -Regimiento de Príncipes, Caída de Príncipes, Trabajos de Hércules de Enrique de $V_{\text {Villena }}{ }^{27} \ldots$ Llamamos la atención sobre este último género literario, muy difundido en los ambientes cortesanos y que no sería aventurado relacionar con la personalidad de los maestres y el proceso de aristocratización vivido por la Orden. Asimismo, conviene subrayar el importante número de libros de historia y crónicas en consonancia con las recomendaciones, ya vertidas en las Parti-

${ }^{24} \mathrm{Vid}$. López Estrada, F.: «Deinde Philosophari. I. ¿Una realidad, las culturas nacionales?. Las literaturas románicas peninsulares»: La época del Gótico en la cultura española (c. 1220-c.1480). Historia de España Menéndez Pidal, Madrid, 2000, vol. XIV, p. 343.

25 El Tesoro forma parte de las obras consideradas enciclopédicas del saber medieval. Incluía, además de algunos de los contenidos habituales en estas obras, la Ética de Nicomaco de Aristóteles y la Retórica de Cicerón (LÓPEZ EstradA, «Deinde Philosophari», p. 351).

${ }^{26} \mathrm{El}$ texto trata sobre la inmortalidad del alma. Recibió el título final de Diálogo o razonamiento en la muerte del marqués de Santillana. Su autor Pedro Díaz de Toledo es considerado uno de los filósofos más destacados del primer Renacimiento. Vid. FernÁndez Conde, F.J.: «Deinde Philosophari. III. Un espíritu, el de Occidente»: La época del Gótico en la cultura española (c. 1220-c.1480). Historia de España Menéndez Pidal, Madrid, 2000, vol. XIV, p. 510.

27 Se trata de una obra de intención claramente doctrinal, vinculada al ejercicio de la caballería. Según el propio autor es espejo actual a los gloriosos cavalleros en armada cavallería. Vid. GómEZ REDONDO, F.: Historia de la prosa medieval castellana. III. Los orígenes del bumanismo. El marco cultural de Enrique III y Juan II, Madrid, 2002, p. 2483. 
das ${ }^{28}$ y el Libro de Apolonio (c.1250) ${ }^{29}$, sobre la lectura de hechos bélicos pasados o presentes que actuaran como estímulo y modelo en el comportamiento militar y la educación a la virtu.

El siguiente inventario de libros conservado, correspondiente a 1526, señala un notable incremento en el número de libros. En esta fecha, la biblioteca contaba con unos 540 volúmenes y un número más elevado de títulos ya que algunos volúmenes tenían más de un título. Había una mayor cantidad de manuscritos que de tomos impresos y el contenido temático era heterogéneo: filosofía (85), teología (80), derecho (68), sermones (62), literatura clásica (35), literatura de la época (30), historia y crónicas (17), diccionarios y gramáticas (16), biblias (16) y otros (29) ${ }^{30}$. Entre los autores con mayor cuantía de obras se encuentran Alfonso X, Aristóteles, Boecio, Ramón Llul ${ }^{31}$, Antonio de Nebrija, Guillermo de Ockhan, San Agustín, San Alberto Magno, San Buenaventura, San Gregorio, Santo Tomás y Duns Scoto. Además es interesante mencionar la presencia de obras de Bocaccio, Petrarca, Pedro López de Ayala, el marqués de Santillana, Fernán Pérez de Guzmán y Alonso Fernández de Palencia. Resulta claro que los libros de filosofía y teología eran los más numerosos, pero los más demandados debieron ser los de derecho, cuyo número pudo ser incluso mayor que el reseñado debido a la pérdida de los primeros folios del inventario.

La comparación entre los inventarios de 1495 y 1526 permite interesantes puntos de reflexión. En la relación de libros del XVI, hallamos notables obras

28 Partida II, Título XXI, Ley XX.

29 Apolonio es un estudioso versado en las doctrinas del trivium con una nutrida biblioteca formada por libros religiosos, clásicos y de historia, donde el héroe rememora fazañas passadas válidas por su valor ejemplar pues el rey de Tiro, característico intelectual del siglo XIII poco proclive al uso de las armas, conoce estos textos, los tiene anotados y los recita en voz alta conforme a un uso común en la práctica escolar del momento. No es de extrañar que se refugiara en este ámbito de erudición para encontrar las respuestas a las adivinanzas de difícil solución interpuestas por el rey Antioco: Encerr.ó)se Apolonio en sus cámaras priuadas/ do tenié sus escritos e sus estorias notadas./ Rezó sus argumentos, las fazanyas passadas,/ caldeas e latines, tres o quatro vegadas (Libro de Apolonio, edición de C. Monedero, Madrid, 1990, est. 22, p. 103).

30 El inventario realizado en 1526 ha sido publicado y estudiado por CASADO QUINTANILLA, B.: «La biblioteca del Sacro Convento de Calatrava», pp. 65-120. La distribución de volúmenes por disciplinas es la que ofrece, como simple orientación global, este mismo autor, a quien seguimos en esta cuestión.

31 En este contexto, resulta oportuno resaltar que la obra de Ramón Llul, Libellus formalitatum per reverendum magistrum Petrum Degui... Raimundo Lulli...editum, llevaba al final de la portada de su edición impresa la siguiente referencia: «fratrem Martinum Almodovar ordinis militiae de calatrava traditae impressoribus et per eos impressae Hispali prima die Martii. Anno ab incarnatione Domini 1491». La referencia procede de un ejemplar de la Biblioteca Ambrosiana de Milán. Sin embargo, el ejemplar de esta obra que conservaba la biblioteca del convento calatravo era manuscrito. El 12 de marzo de ese mismo año el propio Martín Almodóvar volvió a la imprenta sevillana para encargar la impresión de otra obra de Ramón Llul, Jhesu christe gloriose... . Vid. PALAU y DULCET, A.: Manual del librero hispanoamericano. Bibliografía general española e hispanoamericana desde la invención de la imprenta hasta nuestros tiempos con el valor comercial de los impresos descritos, $2^{\text {a }}$ edición, Barcelona, 1954, vol. VII, pp. $716-717, \mathrm{n}^{\mathrm{o}} 143747$ y 143758. 
de literatura humanística — particularmente de Nebrija-, textos de «devotio moderna» — Biblia Pauperum - y, especialmente, varias obras partícipes de un clima de intransigencia religiosa - De diferentiis veteris inter christianos et hebreos de Nicolao de Lira, Tractatus de çensura ecllesiástica abatis de Senis, Nicolao de Lira contra hebreos. Tratatus de offitio misae de mano, Tratado contra Mahoma. El análisis en profundidad de ambos inventarios excede el objetivo de este trabajo, aunque no queremos obviar la cita a un Itinerarium Terrae Sanctae. De marca de pliego que podría corresponder a un ejemplar del Itinerario de la Virgen Egeria desgraciadamente perdido.

A pesar de esto, nada sabemos sobre los gustos específicos de los freires, pero el nivel cultural medio no debía ser muy elevado por la presencia de iletra$\operatorname{dos}^{32}$. No extraña, por tanto, que en la visita realizada al convento de Calatrava en 1468 el abad Guillermo II de Morimond constatara que in conventu nullos fore literatos ${ }^{33}$. Naturalmente que habría excepciones, pero no encontramos aquí ninguna figura de la talla del comendador santiaguista Jorge Manrique o del maestre alcantarino Juan de Zúñiga. El caso del maestre calatravo Enrique de Villena, figura sobresaliente en el panorama literario y científico de la primera mitad del siglo $\mathrm{XV}^{34}$, no puede ser considerado como el de un caballero calatravo cultivado ya que se trata de un elemento ajeno a la Orden que accede al maestrazgo por imposición regia ${ }^{35}$. Además su gobierno efectivo al frente de la institución no fue excesivamente extenso y al finalizar su etapa calatrava centró de nuevo su interés en la vida intelectual. En consecuencia, su compleja obra, su afición por ciencias diversas, su erudición, su conocimiento de varias lenguas y su afán por reunir una notable biblioteca deben contemplarse al margen de su vinculación coyuntural con la Orden de Calatrava.

En definitiva, todo parece indicar que, en el seno de la institución cisterciense, nos encontramos ante un panorama cultural no excesivamente enriquecedor acorde con el contexto general castellano del siglo XV, donde las personalidades excepcionales convivían con un ambiente cultural modesto. Como en tantas otras facetas, los calatravos se comportaron siguiendo las pautas generales de la nobleza a la que pertenecían.

32 Ayala MartíneZ, Las Órdenes militares hispánicas en la Edad Media, pp. 270, 359, 375 y 392.

33 O'CALlaghan, "Difiniciones of the Order of Calatrava enacted by Abbot William II of Morimond, April 2, 1468», p. 244.

${ }^{34}$ La referencia obligada se encuentra en la monumental tesis doctoral de CÁTEDRA GARCía, P.M.: Sobre la vida y la obra de Enrique de Villena, Universidad Autónoma de Barcelona, 1981, 9 vols. Este mismo autor es el editor de su obra completa: Enrique de Villena, Obras completas, 3 vols.: Madrid, 1994-2001. Sobre su vida pueden verse los artículos de GASCÓN VerA, E.: «Nuevo retrato histórico de Enrique de Villena»: Boletín de la Real Academia de la Historia, 175 (1978) 107-143; CÁtedra García, P.M.: «Para la biografía de Enrique de Villena»: Estudi General, 1:2 (1981) 2933; y CÁtedra, P.M. y CARR, D.C.: «Datos para la biografía de Enrique de Villena»: La Corónica, 11 (1982-1983), 293-299.

35 Sobre su maestrazgo vid. RIERA I SANS, J.: «Enric de Villena, maestre de Calatrava»: Estudios Históricos y Documentales de los Archivos de Protocolos, 7 (1979), 109-132. 
Con todo, podemos presentar un caso excepcional de promoción cultural debido a la iniciativa de un freire calatravo. Se trata del encargo de traducir la biblia al romance hecho por el maestre Luis González de Guzmán ${ }^{36}$ al rabino judío Moisés Arragel de Guadalajara, morador en la villa calatrava de Maque$\mathrm{da}^{37}$. El resultado es lo que se conoce en la actualidad como Biblia de la Casa de Alba, que se conserva en la Fundación Casa de Alba de Madrid ${ }^{38}$ (Palacio de Liria, ms. 399) ${ }^{39}$; un códice manuscrito e iluminado de 513 folios que contiene una versión castellana del Antiguo Testamento a partir del hebreo y el latín. El texto bíblico está acompañado de numerosas glosas y figura ilustrado con 334 miniaturas. Los 25 primeros folios incluyen un interesante prólogo que nos permite conocer los avatares de la elaboración del libro ${ }^{40}$. La obra fue encargada por el maestre calatravo cuando, después de sus campañas contra los musulmanes, descansaba con la corte en el monasterio de San Agustín de Toledo.

36 Nuño de Guzmán, hijo del maestre Luis González de Guzmán, aparece documentado como poseedor de libros. Vid. CABrera SÁnChEZ, M.: Nobleza, oligarquía y poder en Córdoba al final de la Edad Media, pp. 398-400.

37 La nobleza, deficiente entendedora del latín, promovió la traducción de la biblia a las lenguas romances. El maestre Guzmán se mostró receloso ante esas transmisiones y optó por encargar al judío Arragel la traducción directa del hebreo. La versión definitiva, no obstante, fue supervisada por personalidades cristianas de la confianza del maestre. Vid. YARZA LUACES, J.: La nobleza ante el rey. Los grandes linajes castellanos y el arte en el siglo XV, Madrid, 2003, pp. 279-280.

${ }^{38}$ La denominación del manuscrito es consecuencia de la posesión del mismo por parte de esta familia nobiliaria.

39 Sobre este tema vid. PAZ y Melia, «La Biblia puesta en romance por rabí Mosé Arraguel de Guadalfajara»; DUQUE DE BERWICK Y AlBA (ed.), Biblia (Antiguo Testamento) traducida del hebreo al castellano por Rabí Mosé de Guadalfajara (1422-1433?), 2 vols.: Madrid, 1920-1922; CASTRO, A.: De la España que aún no conocía, México, 1972, vol. II, pp. 217-225; METZGER, T.: «The Alba Biblia of Rabbi Moses Arragel»: Bulletin of the Jewish Studies, III (1975) 131-135; BAER, Y.: Historia de los judios en la España cristiana, 2 vols.: Madrid, 1981, vol. II, pp. 509-510 y 764; SCHONFIELD, J. (ed.), The Hebrew Bible of the Jews translated into Castilian in 1422 by Rabbi Moses Arragel de Guadalajara, ed. facsímil, with contributions by Ben Ami, S.; Fellous-Rozenblat, S.; Keller, A.; Lazar, M.; Mackay, A. y SCHONFIELD, J.: Madrid, 1992; Burdeus, M.D.: «La traducción al servicio de la Orden de Calatrava»: BuRdeus, M.D.; ReAL, E. Y VerdegAL, J.M.: Las Órdenes Militares: realidad e imaginario, Castellón, 2000, 223-242.

En la actualidad, la gran especialista sobre la Biblia de Alba, a la que ha consagrado su tesis doctoral, es Fellous, S.: La Bible d'Albe. Moüse Arragel de Guadalajara. Contribution à l'étude des rapports entre juifs et chrétiens dans l'Espagne médiévale, Thése de Nouveau Doctorat, 2 vols.: París, 1993. Entre sus numerosas publicaciones sobre el tema, destacamos aquí FelLous, S.: «Un Bible à la recontre des cultures»: GlÉnisson, J. (ed.), Le livre au Moyen Âge, París, 1988, 148-154; Fellous, «Un juif traduit l'Ancien Testament pour un chrétien»: BENBASSA, E. (ed.), Transmission et Passages en monde juif, París, 1997, 119-136; Fellous, «La Biblia de Alba. Traduction et exégese»: SOTO RÁbanos, J.M.: Pensamiento hispano medieval. Homenaje a Horacio Santiago Otero, Madrid, 1998, 1601-1624; y, sobre todo, Fellous, S.: Tolède 1422-1433. Histoire de la Bible de Moïse Arragel. Quand un rrabin interprète la Bible pour les chrétiens, París, 2001.

40 Fellous, «Dialogue et Prologue dans la Biblia d'Albe»: Roussel, D. y Dubois, J.D.: Les Prologues et Préfaces de la Bible, XVème-XVIIème siècles, París, 1997, 359-376. 
El mandado se hizo el 22 de abril de 1422. Nueve años después, en concreto el 2 de junio de 1430, Arragel concluía la obra en Maqueda; en las mismas fechas el maestre y el comendador mayor Juan Ramírez de Guzmán se encontraban en Pastrana, reclutando gente para la guerra contra los reyes de Navarra y Aragón. Probablemente el trabajo de revisión y corrección del texto se alargó hasta 1433 , cuando el rabino afirmó que había empleado once años en su tarea, a pesar de no haber cobrado todavía su trabajo, que valoraba en 1.000 doblas $^{41}$.

Al inicio del prólogo se incorpora una carta del maestre con los motivos que determinaron el patrocinio del texto bíblico:

Nos, el maestre de Calatrava, enviamos mucho saludar a vos, rabí Mosé Arragel, nuestro basallo en la nuestra villa de Maqueda...Es nos dicho que soys muy sabio en la ley de los judíos, e que ha poco que ende venistes a morar...Sabed que auemos cobdiçia de vna biblia en rromançe, glosada e ystoriada, lo qual nos dicen que soys para la fazer assy muy bastante. E a la asy demandar nos mouio dos cosas: una, que las biblias que oy sson falladas el su romançe es muy corrupto; segunda, que los tales como nos avemos necesario la glosa para los passos obscuros; que Dios sabe que en los tienpos que esentos nos quedan del persegimiento de los maluados moros, enemigos de la santa ffe catholica, o del segimiento del pro e seruiçio de nuestro señor el rrey e honor de los sus reynos, segund que conuiene a la nuestra orden, que nos mas querriamos dar en acuçia de oyr de biblia, a fin de con Dios contemplar, que yr a caça o oyr los libros ystoriales o poetas, o jugar axedres o tablas o sus semejantes juegos: que manifiesto es que por lo vno se gana la bienandança e la fellicidat, e es esta bien andança verdadera por seer ley de Dios; e por lo otro se desuia e aparta el omne de esta bien andança: que nos veemos que los reyes e señores, sso color de ociosidat desechar e malos penssamientos euitar, han su acuçia en lo que dicho es, e apenas se acuerdan de leer en la ley de Dios. E como dezimos, la nesçecidat de los trabajos scecantes, luego es en casa oçiosydat. Pero en quanto nos, querriamos tanto que despues de dichas las oras, oyr de biblia en los tiempos possybiles ${ }^{42}$.

La misiva expresa claramente la intención del comitente: disponer de una buena traducción de la Biblia en castellano con glosas para los fragmentos más difíciles de comprender e ilustraciones para un mejor seguimiento del texto. Los propósitos del maestre revelan que estamos ante un hombre no excesivamente versado en el latín y la exégesis del libro sagrado, circunstancias no infrecuentes entre la nobleza de su tiempo. Puede sorprender algo más por tratarse de un maestre, cabeza visible de una institución religiosa, pero no debemos olvidar que se trata también del máximo representante del brazo se-

41 PAZ Y MELIA, «La Biblia puesta en romance por rabí Mosé Arraguel de Guadalfajara», pp. 6,12 y 18 .

42 Fundación Casa de Alba (Madrid), ms. 399, fols. 1v-2r. Publ. DuQUe DE BerWiCK y AlBA, Biblia traducida del hebreo al castellano por Rabi Mosé de Guadalfajara, I, pp. 1-2 (la transcripción corresponde a Antonio Paz y Mélia y a Julián Paz).

Hispania, 2006, vol. LXVI, $\mathrm{n}^{\circ}$. 222, enero-abril, 199-242, ISSN: 0018-2141 
cular de una Orden sometida a un creciente proceso de aristocratización. El encargo de una biblia romanceada entronca con la tradición iniciada por Alfonso $\mathrm{X}$, contando con el valor añadido de que, como indica el prólogo, el Antiguo Testamento en la Biblia de Alba es una traducción directa del hebreo al castellano.

El maestre controla el encargo y su contenido, promoviendo así un mensaje favorable a su figura y a sus intereses a través de la palabra escrita, las imágenes y la propia obra en su conjunto. En cualquier caso, nos encontramos ante un encargo maestral que constituye para algún autor el más rico manuscrito iluminado del siglo XV castellano en el que participaron varios miniaturistas cristianos $^{43}$. Ana Domínguez, por su parte, opina que las ilustraciones son rústicas, alejadas de las novedades compositivas trecentistas y sin el refinamiento característico de la estética internacional. La peculiaridad de las miniaturas, concluye la citada autora, reside en que algunas tienen una influencia hebrea ${ }^{44}$.

\section{LA REPRESENTACIÓN DEL PODER DE LA NOBLEZA CALATRAVA}

\subsection{Poder y exhibición de símbolos}

Los símbolos propios de la nobleza ${ }^{45}$ son utilizados también por los caballeros calatravos. Así el apellido, las armas o el sello remarcaban la condición noble y la manifestaban a la sociedad. Los símbolos se exhibían también de una manera teatral mediante las celebraciones sociales como entierros o fiestas y la ostentación pública. El poder se manifestaba además en clave simbólica a través del mantenimiento de cortes maestrales, la cercanía a la persona del rey, la configuración de facciones nobiliarias y el ejercicio de la jurisdicción señorial ${ }^{46}$, que debía ser particularmente visible en las tomas de posesión ${ }^{47}$ de las diferentes jerarquías calatravas. De tal suerte que el potencial simbólico desplegado por la nobleza calatrava nada tenía que envidiar al que exteriorizaba la nobleza laica.

43 CaAmaño Martínez, J.Mª, «Arquitectura y artes plásticas». En La época del gótico en la cultura española (c.1220-c.1480). Historia de España Menéndez Pidal, Madrid, 2000, vol. XVI, p. 740.

44 Domínguez Rodríguez, A.: «Dos Biblias iluminadas en Toledo en torno a 1420: La Biblia de Alba y la "Biblia romanceada escurialense" (Escorial, Ms. I.J.3)»: Flanders in a European Perspective, Lovaina, 1995, 473-485, p. 474.

45 Un ejemplo concreto en Palencia Herrejón, J.R.: «Elementos simbólicos de poder de la nobleza urbana en Castilla: los Ayala de Toledo al final del Medievo»: En la España Medieval, 18 (1995) 163-179.

46 Estas cuestiones, referidas a la nobleza en general, están explicitadas por una de las grandes especialistas en la materia. Vid. QUINTANILLA RASO, «La renovación nobiliaria en la Castilla bajomedieval. Entre el debate y la propuesta», pp. 293-295.

47 BeCEIRo PitA, I.: «La imagen del poder feudal en las tomas de posesión bajomedievales castellanas»: Stvdia Historica. Historia Medieval, 2 (1984) 157-162; y «El escrito, la palabra y el gesto en las tomas de posesión señoriales», Stvdia Historica. Historia Medieval, 12 (1994), 53-82; QuINTANILLA RASO, M.C.: «El orden señorial y su representación simbólica. Ritualidad y ceremonia en Castilla a fines de la Edad Media», Anuario de Estudios Medievales, 29 (1999) 843-873. 
Durante el siglo XV los freires calatravos utilizan conscientemente el apellido de manera reiterada, lo que en centurias anteriores constituía la excepción, ahora se impone como regla. Se trata de un apellido que en no pocas ocasiones contiene patronímico y cognomen, pero en todo caso se cuida que identifique al personaje con el linaje al que pertenece.

La representación de una mentalidad nobiliaria incluía necesariamente la exhibición de símbolos a la manera de la alta aristocracia y la realeza. Los maestres calatravos tenían derecho a llevar el pendón, las señales y preeminencias propias de su dignidad. Juan II subrayaba este privilegio al confirmar sus cargos a los maestres Luis González de Guzmán ${ }^{48}$ y Pedro Girón ${ }^{49}$. Algunos de los estandartes maestrales con cruces florilisadas negras o rojas sobre damasco blanco se conservaban en la iglesia del convento de Calatrava la Nueva todavía a mediados del siglo XVII ${ }^{50}$.

Además de las insignias privativas de la Orden, en los sepulcros, capillas funerarias y obras arquitectónicas los maestres publicitan las armas de sus propios linajes. Así sucedió en la iglesia del convento de Calatrava la Nueva, donde se representaron con notable profusión los escudos de los Guzmán, los Padilla y los Girón ${ }^{51}$ o en el palacio maestral de Almagro adornado con las armas de los Guzmán y los Girón ${ }^{52}$.

Esta práctica, no constatada en la Orden de Calatrava antes de finales del siglo XIV, demuestra la importancia que para los freires tenía su pertenencia al linaje. Por otra parte, no es una casualidad que el iniciador de esta tendencia entre los calatravos fuera el maestre Gonzalo Núñez de Guzmán, cuya etapa al frente de la Orden supone el inicio del control de la institución por parte de determinadas familias nobiliarias.

\subsection{Iconografía y poder: la representación de la «monarquía maestral»}

Iconografía y poder se unen de manera paradigmática en la representación de Luis González de Guzmán incluida en el folio 25v de la Biblia de la Casa de Alba [figura $\mathrm{n}^{\mathrm{o}} 1$ ].

48 AHN, OO.MM.: Calatrava, carp. 432, $\mathrm{n}^{\circ} 240$.

49 AHN, Nobleza, Osuna, leg. $41, \mathrm{n}^{\circ} 2$ y leg. $98, \mathrm{n}^{\circ} 3$.

50 CotTa y Márquez del Prado, F. DE, «Descripción del Sacro Convento y Castillo de Calatrava la Nueva, Cabeza y Casa mayor de esta Orden y caballería y de sus rentas y casas»: La Mancha, vol. $1, \mathrm{n}^{\mathrm{o}} 1$ y 2 (1961) 35-76 y 24-34, pp. 44-45. Esta descripción de mediados del siglo XVII fue publicada con anterioridad por CASTAÑEDA Y ALCOVER, V.: «Descripción del sacro convento de Calatrava la Nueva». Boletín de la Real Academia de la Historia, 28 (1928) 402-443.

51 CotTa y Márquez del Prado, «Descripción del Santo Convento de Calatrava la Nueva», pp. 37-44.

52 Espino Nuño, J.: «El palacio de los Maestres de la Orden de Calatrava en Almagro en el siglo XV: nuevos datos documentales acerca de su construcción»: Homenaje al profesor Dr. D. José María de Azcárate y Ristori. Anales de Historia del Arte, 4 (1993-1994) 91-99, pp. 93 y 99. 


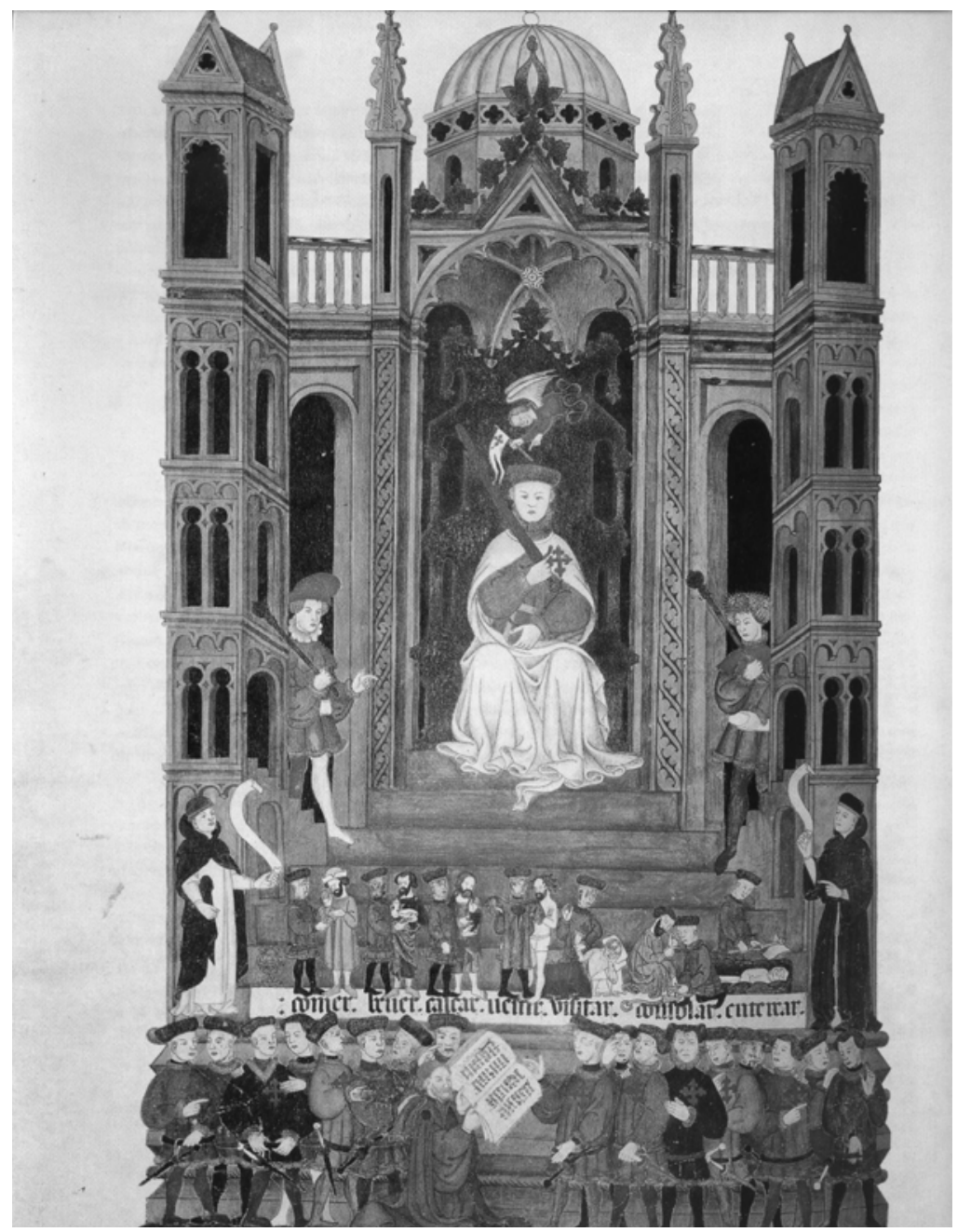

Figura $^{\circ}{ }^{0}$. Biblia de la Casa de Alba. Entrega de la biblia al maestre Luis González de Guzmán (fol. 25v). Fundación Casa de Alba, Madrid.

El maestre calatravo encargó la traducción del texto bíblico al rabino judío Moisés Arragel de Guadalajara. El libro, según una costumbre frecuente en la época, se completa con un variado elenco de miniaturas ${ }^{53}$, atribuidas por algu-

53 El estudio de las miniaturas desde una perspectiva artística en NORDSTRÖM, C.O.: The Duke of Alba's Castilian Bible. A Study of the Rabbinical Features of the Miniatures, Uppsala, 1967; YARZA 
nos estudiosos a miniaturistas toledanos ${ }^{54}$ que, preferentemente, secundan las directrices del gótico internacional ${ }^{55}$.

Particular atención merece la citada miniatura donde Arragel ofrece la biblia al maestre calatravo. Parece que la escena no había tenido lugar cuando se pintó, ya que Luis de Guzmán estaba ocupado en los preparativos de la guerra con Aragón y no pudo recibir el manuscrito de la mano del rabino. La ceremonia pudo realizarse con posterioridad, pero en todo caso lo verdaderamente importante es la intención del maestre de ser representado con esta grandilocuente iconografía.

Es una escena de estructura piramidal en la que el maestre se sitúa en la cúspide de la pirámide y el rabino y varios caballeros calatravos en la base. Para resaltar la superioridad y el poder ejercido por Luis de Guzmán se utiliza el viejo recurso de la perspectiva jerárquica; de tal forma que la figura maestral, a pesar de estar sentada, es claramente superior a las otras personas representadas en la miniatura. Yarza ha subrayado el italianismo de la composición visible en los juegos de perspectiva que contribuyen a remarcar la solemnidad de la escena. Esta influencia puede derivarse de la presencia anterior del pintor florentino Gerardo Starnina en Toledo y su impronta en este ámbito ${ }^{56}$.

Una arquitectura rematada por una cúpula dorada semiesférica de antiguas connotaciones cósmicas ${ }^{57}$ cobija el trono empleado como asiento del maestre ${ }^{58}\left[\right.$ fi- $^{-}$

LUACES, «La imagen del rey y la imagen del noble en el siglo XV», pp. 281-284; Fellous, «La Bible du duc d'Albe»: Mentré, M. (dir.), L'Art juif au Moyen Âge, París, 1988, 208-214; Fellous, "Catalogue Raisonné of the Miniatures»: SCHONFIELD, J. (ed.), The Hebrew Bible of the Jews translated into Castilian in 1422 by Rabbi Moses Arragel de Guadalajara, ed. facsímil, Madrid, 1992, 79-146; Fellous, La Bible d'Albe. Mö̈se Arragel de Guadalajara. Contribution à l'étude des rapports entre juifs et chrétiens dans l'Espagne médiévale; DOMínguez RODRÍGUEZ, "Dos Biblias iluminadas en Toledo en torno a 1420: La Biblia de Alba y la "Biblia romanceada escurialense" (Escorial, Ms. I.J.3)»; FELlous, S.: «La Biblia de Alba. L'iconographie ambigüe»: CARrete Parrondo, C. Y MeyUhas Gimio, A. (eds.), Creencias y Culturas. Cristianos, judíos y musulmanes en la España medieval, Salamanca, 1998, 41-96; y Fellous, Tolède 1422-1433. Histoire de la Bible de Moüse Arragel. Quand un rrabin interprète la Bible pour les chrétiens.

54 Éstos debieron seguir las instrucciones del franciscano Arias de la Encina, que pudo enseñarles como modelo la Biblia del Sagrario de la catedral de Toledo, muy bien historiada. Vid. PAZ Y MeLIA, «La Biblia puesta en romance por rabí Mosé Arraguel de Guadalfajara», p. 10.

55 CAAMAÑo MARTínEZ, «Arquitectura y artes figurativas» p. 740.

56 YARZA LUACES, «La imagen del rey y la imagen del noble en el siglo XV», p. 281. Sobre este foco artístico vid. la monografía de PIQUERo LÓPEZ, M.A.B.: La pintura toledana anterior a 1450 (el Trecento), 2 vols.: Toledo, 1984.

57 Para Yarza, el simbolismo de la cúpula se «aplica tanto a Dios como al emperador o soberano por la gracia de Dios...Es evidente que se ha querido presentar al noble como un nuevo Salomón, rey paradigmático, ejemplo de monarca para todos los emperadores, reyes y gobernantes cristianos» (YARZA LUACES, «La imagen del rey y la imagen del noble en el siglo XV», p. 282).

58 La miniatura cuenta con elementos que pueden remitir a la tradición islámica como el arriaz curvado de la espada maestral y el remate de la cúpula similar a la forma característica del yamur empleado en los alminares. 
gura $\mathrm{n}^{\mathbf{0}} 2$ ]. Los seis peldaños que lo elevan, alusivos a las seis virtudes de la Virgen, definen el modelo iconográfico del trono de Salomón ${ }^{59}$.

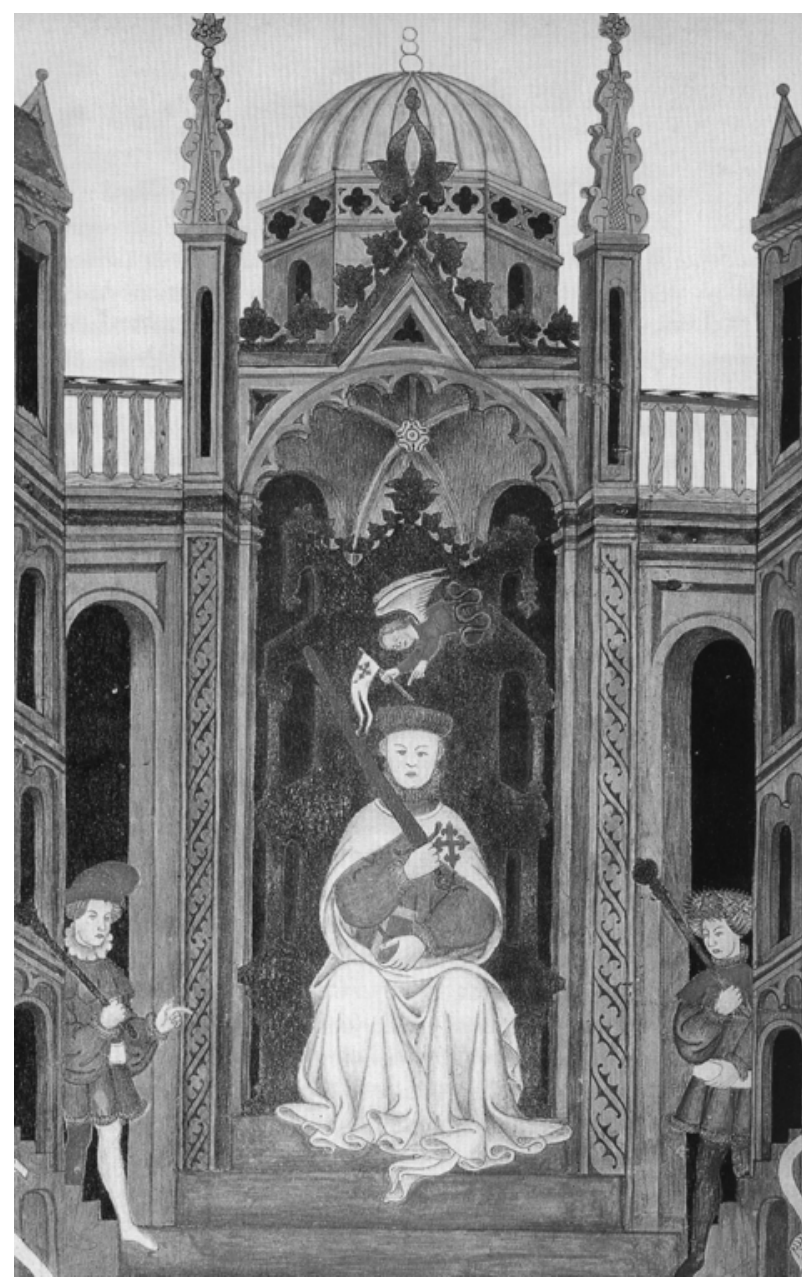

Figura $\mathrm{n}^{\circ} 2$. Biblia de la Casa de Alba. Entrega de la biblia al maestre Luis González de Guzmán. Detalle superior: el maestre entronizado (fol. 25v). Fundación Casa de Alba, Madrid.

59 El tema fue difundido por los dominicos y, aunque cuenta con precedentes que se remontan al siglo XII, se hace más frecuente en el transcurso del siglo XIV. Vid. L. RÉAU, Iconografía del arte cristiano. Iconografía de la Biblia. Antiguo Testamento, Barcelona, 1996, pp. 342-343. 


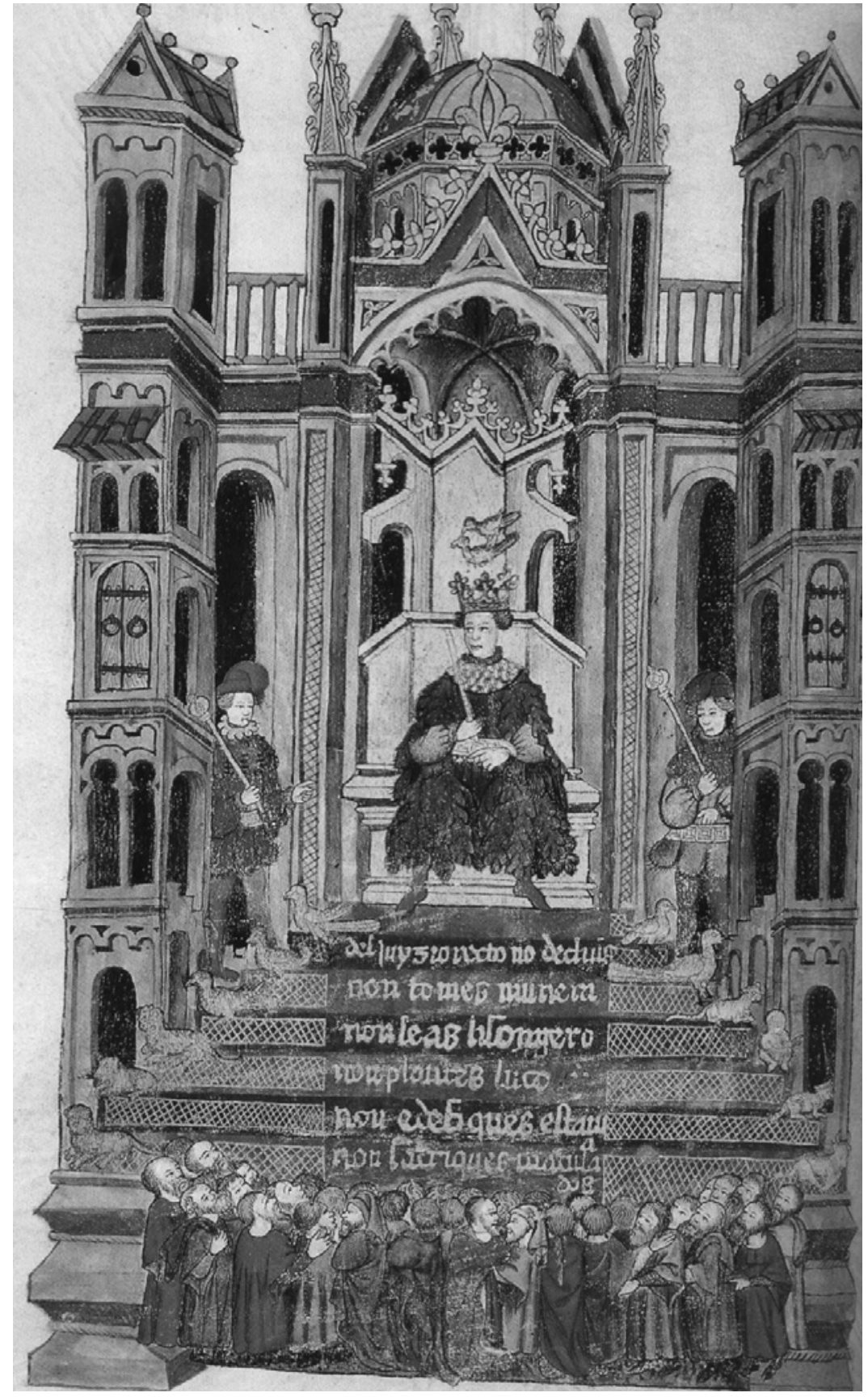

Figura $n^{\circ}$ 3. Figura $n^{\circ}$ 4. Biblia de la Casa de Alba. Salomón (fol. 235v). Fundación Casa de Alba, Madrid. 
La pose mayestática del maestre ${ }^{60}$, además, plantea unos sutiles paralelismos con la miniatura que la Biblia de Alba dedica al citado gobernante israelita (fol. 235v) [figura $\mathbf{n}^{\mathbf{o}}$ 3]. El hecho no es azaroso. La literatura y el arte del momento son prolijos en la búsqueda de precedentes veterotestamentarios que actúan como legitimadores del quehacer gubernativo. Recordemos, en ese sentido, la galería de monarcas bíblicos que Gil de Siloé cinceló en las paredes del cenotafio de Juan II de la Cartuja de Miraflores (Burgos). En la Biblia de Alba, frente a otros referentes bíblicos, se opta por Salomón como paradigma de gobernante justo y sabio.

El maestre Luis González de Guzmán figura entronizado bajo una suerte de hornacina o baldaquino con la espada a la manera regia ${ }^{61}$. Con acierto, Yarza afirma que ninguna visión mayestática del siglo XV castellano alcanza el grado de insolencia de ésta ${ }^{62}$. Sobre la cabeza del maestre, un pequeño ángel con el dedo índice extendido, reproduciendo el ancestral gesto de los mensajeros, le designa como el elegido por la divinidad, sacralizando así su poder. El emisario divino lleva además un pendón farpado maestral. Luis de Guzmán sujeta el Libro Sagrado, mientras que envuelve su túnica de terciopelo con una elegante capa blanca decorada con la cruz de Calatrava. La imagen de poder terrenal se refuerza por los dos pajes con mazas que flanquean al maestre y confieren a la escena un carácter cortesano, así como por el grupo de freires calatravos situados en la grada inferior con vestidos de colores variados, espadas y la cruz roja en el lado superior izquierdo del pecho como símbolo de pertenencia a la Or-

60 Por citar sólo ejemplos del ámbito hispano puede relacionarse con las representaciones regias contenidas en el Llibre de franqueses i privilegis del regne de Mallorca, realizado entre 1334 y 1339. También es comparable con algunas de las miniaturas (c. 1420-1430) contenidas en el códice titulado Cástigos y documentos para buen vivir del rey don Sancho (Biblioteca Nacional, Madrid, ms. 3.995). Estas miniaturas, tradicionalmente consideradas como procedentes del ámbito toledano, recogen representaciones de monarcas entronizados con la espada a la manera del maestre (fols. 14r y 22r). Vid. Domínguez Rodríguez, «Dos Biblias iluminadas en Toledo en torno a 1420: La Biblia de Alba y la "Biblia romanceada escurialense" (Escorial, Ms. I.J.3)», pp. 473-474.

61 Yarza piensa que, pese al buscado equívoco, el maestre porta la espada para aludir al carácter militar de la Orden (YARZA LUACES, «La imagen del rey y la imagen del noble en el siglo XV», p. 282). Sobre el simbolismo de la espada vid. PALACiOs MARTín, B.: «Los símbolos de la soberanía en la Edad Media española. El simbolismo de la espada»: VII Centenario del infante don Fernando de la Cerda, Ciudad Real, 1976, 273-296. Las Partidas reiteran insistentemente el símil espada-justicia al hablar del quehacer regio, como ejemplifican las frases: rey taja los males del reino con la espada de la justicia y el nome del Rey es de Dios e tiene su lugar en tierra para hazer justicia (Alfonso X, Segunda Partida, Título IX, Ley XXVII y Título XIII, Ley I). Por el contrario, los actos indecorosos son incompatibles con la posesión de este arma. En la Crónica de Jiménez de Rada, Witimiro fue desarmado de la espada por los godos tras gritar cosas irreverentes ante el altar mariano (Historia de los Hechos de España, int.: trad.: notas e índices de J. Fernández VALVerde, Madrid, 1989, Libro 3, Cap. V, pp. 25-26); en la misma línea, se encuadra la penalización impuesta en las Partidas a los malos caballeros de cortarles las espuelas o la espada que tuviesen ceñida (Alfonso X, Sétima Partida, Título VI, Ley IIII). Trata el tema monográficamente FLORI, J.: L'ideologie du glaive. Prehistoire de la chevalerie, Ginebra, 1983.

62 YARZA LUACES, «La imagen del rey y la imagen del noble en el siglo XV», p. 281. 
den militar, tal como indicaba la bula de Benedicto XIII de 1397. Se trata de 17 nobles caballeros de la Orden, entre los que muy probablemente se encuentran el comendador mayor, el clavero y los más importantes comendadores. La mayoría aparecen conversando, uno de forma particular señala el texto bíblico y otros tres miran frontalmente al espectador, entre los que llama la atención un caballero con la mano en el pecho sobre la túnica negra. Su atuendo responde a la moda aristocrática de la época: elegante túnica rematada en sus extremos por pieles, calzas y cinturones caídos de los que penden espadas en referencia al carácter militar de la institución a la que pertenecen estos nobles.

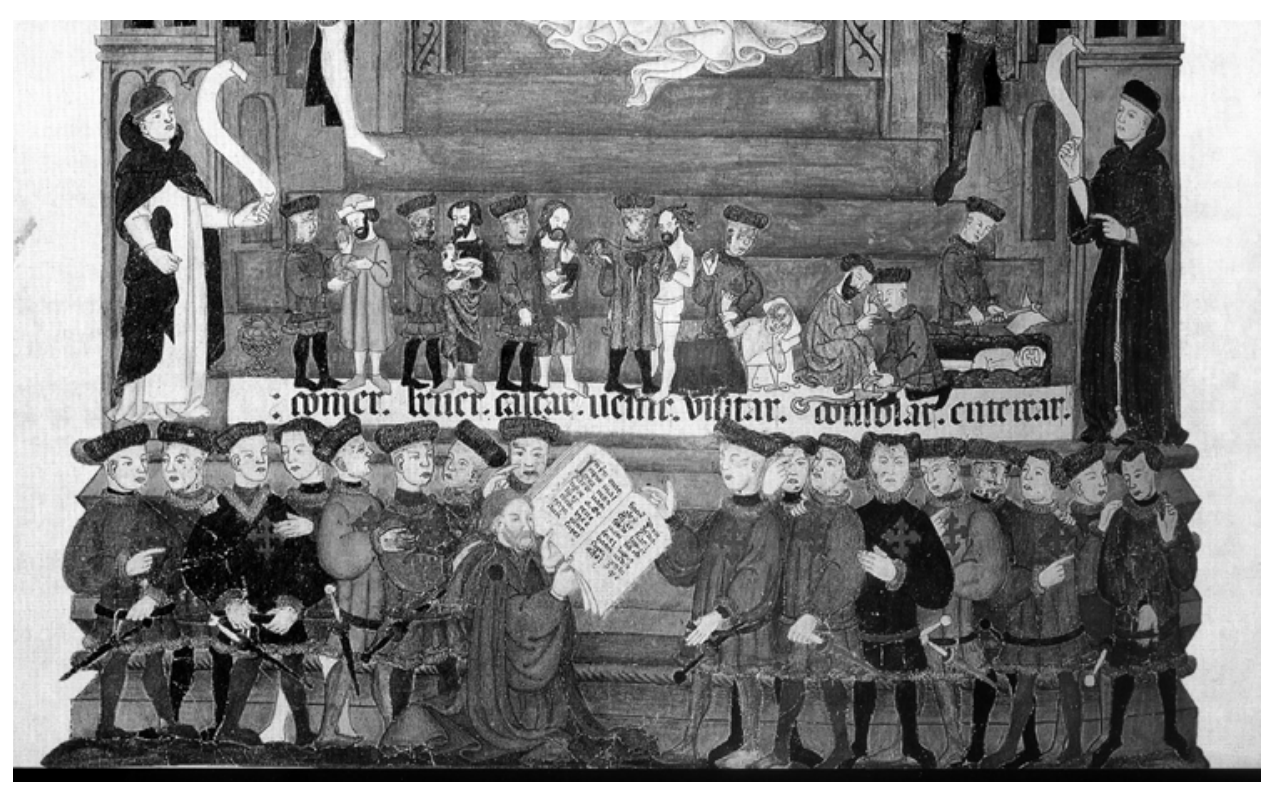

Figura $n^{\circ}$ 4. Biblia de la Casa de Alba. Entrega de la biblia al maestre Luis González de Guzmán. Detalle inferior: comendadores calatravos y el judío Moisés Arragel presentando la biblia al maestre (fol. 25v). Fundación Casa de Alba, Madrid.

La hilera de caballeros calatravos se interrumpe en su centro para enfatizar la entrega de la biblia traducida, verificada por el rabino Moisés Arragel a Luis de Guzmán [figura $\mathbf{n}^{\mathbf{0}}$ 4]. La imagen reproduce la fórmula iconográfica característica de las escenas de presentación codificadas en la miniatura alfonsí tanto en el asunto —ofrecimiento del mandato ya cumplido - como en la resolución compositiva — pose genuflexa del autor y priorización del mecenas-63. ${ }^{63}$ La sustitución del rey por el maestre en la Biblia de Alba es un claro indicio de las

63 Domínguez Rodríguez, A.: La miniatura en la Corte de Alfonso X, Madrid, 1992. 
aspiraciones de este último. Arragel, a diferencia de los lampiños caballeros calatravos, tiene barba y círculo distintivo de su condición de judío. El libro aparece abierto por el comienzo del Génesis y reproduce paradójicamente el texto de la Vulgata latina en lugar de la traducción romance.

Los tonos variados y vistosos, particularmente los de las vestimentas de los pajes y los freires, subrayan el carácter cortesano de la escena y la alejan del colorido característico de una orden religiosa. Conviene recordar, en este sentido, que los caballeros calatravos debían vestir de acuerdo con la regla el escapulario cisterciense, aunque desde 1397 sin la capucha característica. No obstante, y debido al proceso de aristocratización que experimentó la institución, las prescripciones sobre las vestimentas se relajaron en el transcurso del último siglo medieval.

Más abajo, entre los caballeros y el maestre, figura la secuencia múltiple de las siete obras de misericordia, apropiados para una Orden de dimensión religiosa y hospitalaria: dar de comer a los hambrientos, de beber a los sedientos, calzar a los descalzos, vestir a los desnudos, visitar a los enfermos, consolar a los afligidos y enterrar a los muertos. La escena se representa con un esteriotipo de caballero calatravo, alusivo al propio maestre ${ }^{64}$ como símbolo y cabeza de la Orden o a una personificación de la propia institución religioso-militar, realizando estas obras con personajes necesitados, algunos de los cuales calzan los característicos borceguíes puntiagudos de la época ${ }^{65}$.

Cierran la composición dos frailes de mayor tamaño, pertenecientes a las dos órdenes mendicantes - franciscanos y dominicos- que mejor simbolizan estas obras de misericordia; ambos portan filacterias sin inscripción. Para Nordström, representan al dominico Juan de Zamora, que revisó el texto de la traducción final, y al franciscano Arias de Encina, colaborador del rabino judío ${ }^{66}$, que señala con su dedo índice hacia las obras de misericordia. Sin embargo, no aparece ninguna referencia iconográfica al brazo clerical de la Orden calatrava en una miniatura que ilustra el texto sagrado por antonomasia. Se trata de un signo más de la preponderancia de los elementos laicos sobre los clericales, materializada en la atmósfera eminentemente cortesana que predomina en toda la composición y que tan alejada resulta de la espiritualidad conventual característica de una orden religiosa.

El poder visual de esta iconografía mayestática no es posible concebirlo al margen del proyecto político de Luis González de Guzmán de hacer del maestrazgo una auténtica «monarquía calatrava», con una autoridad extraordinaria

${ }^{64}$ Esta es la opinión de YARZA LuACES, «La imagen del rey y la imagen del noble en el siglo $\mathrm{XV} »$, p. 282.

${ }^{65}$ La práctica de las siete obras de misericordia es un lugar común de los actos piadosos del siglo XV, lo que justifica la fundación de un crecido número de hospitales como crisol de la actividad caritativa. Sobre el tema vid. YARZA LUACES, J.: La nobleza ante el rey, pp. 206-209.

66 Nordström, The Duke of Alba's Castilian Bible. A Study of the Rabbinical Features of the Miniatures, p. 26. 
en el seno de la Orden, al tiempo que pretendía compatibilizar este cargo comportándose como un gran noble de su tiempo. El maestre calatravo consiguió de las autoridades eclesiásticas importantes ventajas que aceleraron el proceso de secularización de la Orden y le permitieron mitigar los condicionantes de su pertenencia a una institución eclesiástica. De tal suerte que pudo patrimonializar bienes y rentas de la Orden, incorporar encomiendas a la mesa maestral con el consentimiento papal y disponer prudentemente de sus bienes, tanto en vida como para después de su muerte, por autorización del abad Juan IV de Morimond ${ }^{67}$. Además, durante su maestrazgo, el papa Eugenio IV autorizó a los freires calatravos, que no hubieran recibido órdenes sagradas, a contraer matrimonio con la condición de mantener el voto de castidad conyugal. Los hijos habidos en el matrimonio podrían heredar los bienes de sus padres siempre que éstos no se hubieran adquirido a través de la Orden ${ }^{68}$. Se trataba de una medida de carácter generalizador que, sin embargo, afectaba particularmente al maestre. La bula papal, fechada en febrero de 1440, debió ser utilizada pronto por Luis González de Guzmán, muerto en 1443, para casarse con Inés de Torres, la madre de sus hijos ${ }^{69}$.

Esta última medida entronca con la mentalidad nobiliaria del maestre, que como todo gran noble de su tiempo, tuvo como objetivo principal la creación de un señorío laico para el primogénito, mientras que al resto de sus descendientes intentó dejarles una herencia decorosa. De tal suerte que el hijo mayor, Juan, por autorización apostólica, estaba destinado a heredar el señorío de Andújar que Juan II había donado a su padre, pero la oposición de sus habitantes propició que en su lugar se le concediera Medina Sidonia, villa que pronto permutó con el conde de Niebla por La Algaba. Juan de Guzmán casó con otro miembro del linaje, Elvira de Guzmán. De este matrimonio procede la casa de los marqueses de La Algaba. Otro hijo del maestre, de nombre Pedro, fue comendador calatravo de Almodóvar. Por su parte, un tercer hijo varón, Fernando, fue cabeza de otra rama del linaje Guzmán, mientras que la hija del maestre, Inés de Guzmán, contrajo matrimonio con Gil González de Ávila, señor de Cespedosa y la Fuente del Congosto ${ }^{70}$, desplegando así las mismas estrategias de consolidación de alianzas que practicaba la nobleza laica.

Si en la escena de la entrega de la Biblia el maestre aparece representado como un rey paradigmático con un poder sacralizado, en una miniatura anterior correspondiente al folio $1 \mathrm{v}$ de la misma Biblia de Alba se le representa como un auténtico noble: sentado en una silla alta y con un halcón en la mano,

${ }_{67}$ AHN, OO.MM.: sign. 1348 c, Registro de Escrituras de la Orden de Calatrava, VIII, fol. 44. Publ. O'Callaghan, J.: «Las Definiciones de la Orden de Calatrava, 1383-1418»: En la España Medieval, 19 (1996) 99-124, p. 124, n 9.

68 AHN, OO.MM.: sign. 1348 c, Registro de Escrituras de la Orden de Calatrava, VIII, fols. 83-84. Publ. Ortega y Cotes, I.J.; Álvarez de Baquedano, F. y Ortega Zúñiga y Aranda, P. De, Bullarium Ordinis Militiae de Calatrava, Madrid, 1761, ed. facsímil, Barcelona, 1981, pp. 248-249.

69 RADES Y ANDRADA, Chronica de Calatrava, fol. 69v.

70 RADES y ANDRADA, Chronica de Calatrava, fols. 70r-70v. 
mientras ordena el envío de una carta a Moisés Arragel de Guadalajara. La carta la lleva en la mano un caballero calatravo, que aparece acompañado por otros dos nobles de la Orden [figura $\mathbf{n}^{\mathbf{0}}$ 5]. Se resumen así en estas dos representaciones las dos facetas de la vida de Luis González de Guzmán: la naturaleza monárquica de la institución maestral que ostentaba y su condición de noble perteneciente a uno de los más antiguos linajes castellanos.

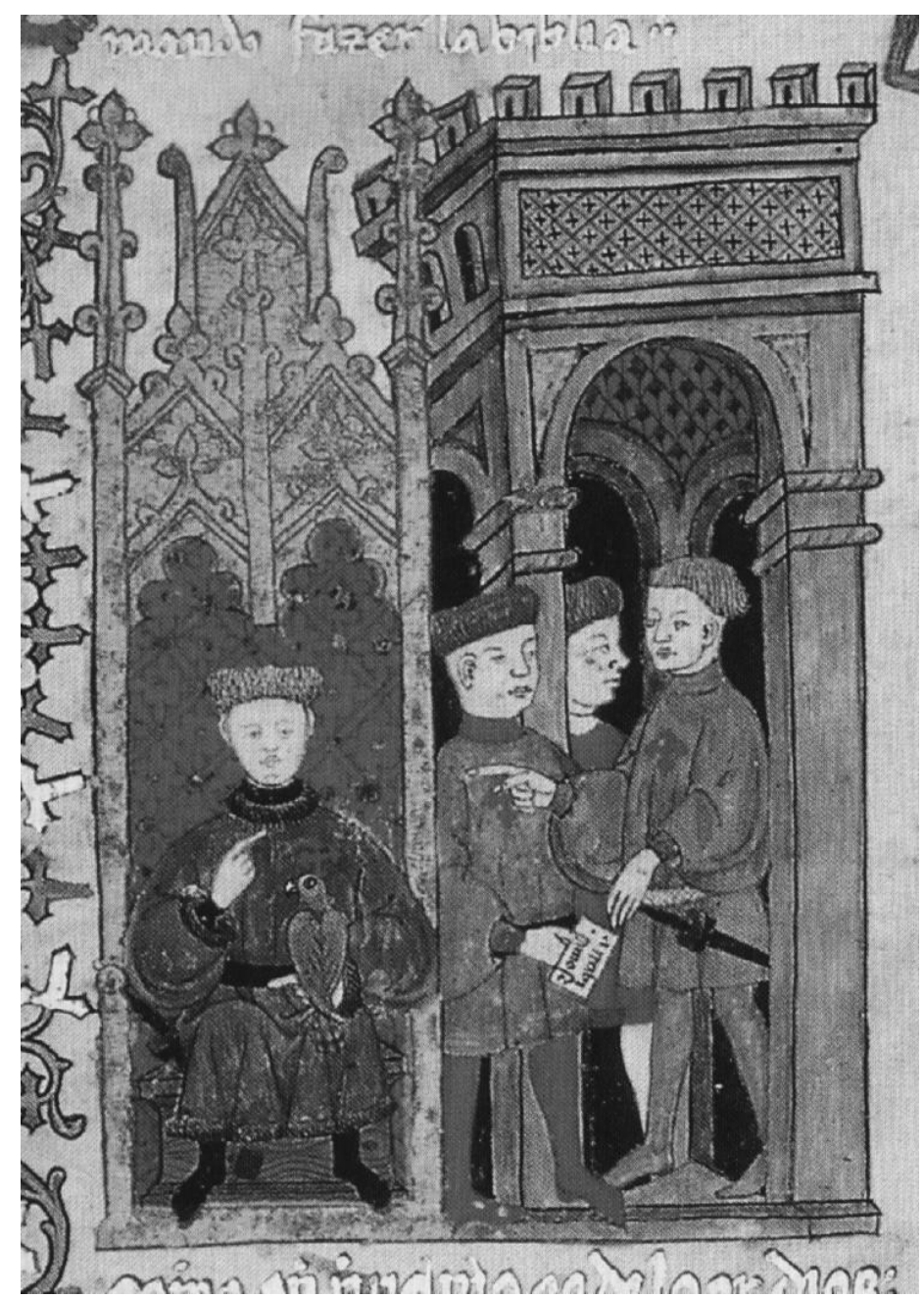

Figura n ${ }^{\circ}$ 5. Biblia de la Casa de Alba. El maestre Luis González de Guzmán con un halcón en la mano y junto a caballeros calatravos(fol. 1v). Fundación Casa de Alba, Madrid. 


\subsection{La sustitución del castillo por el palacio}

Naturalmente, los maestres eran los que contaban con mayores recursos para sufragar obras artísticas, pero no eran los únicos. Los comendadores promovieron la elevación de residencias palaciegas en sus encomiendas en las que destacaban la altura de la torre, con un poder coercitivo que remite a la torre del homenaje de los castillos, la existencia de jardines y estanques de decidida vocación lúdica y la exhibición de las armas de sus promotores en las fachadas ${ }^{71}$. Estas «casas de la encomienda», que la propia documentación de la época denomina significativamente "palacios» o «casas prinçipales», oscilaban en dimensiones y calidad en función de las rentas del comendador correspondiente. Presumiblemente destacaban las residencias que el comendador mayor tenía en las villas de Agudo y Abenojar, que a finales del siglo XV se encontraban en perfecto estado de conservación, circunstancia infrecuente en otras casas comendatarias de la época. Otra casa-palacio que estaba en buen estado en ese período era la de Puertollano. Por su parte, la encomienda de El Viso y Santa Cruz de Mudela contaba con dos «casas de palacio», una en cada población de esta tenencia calatrava ${ }^{72}$.

Este gusto por el palacio, propio de la mentalidad nobiliaria que exhiben los comendadores, se materializa en el abandono del emplazamiento elevado de los viejos castillos y su sustitución por otras casas de la encomienda insertadas plenamente en el casco urbano. La práctica la inauguraron los propios maestres al dejar, en el tránsito de los siglos XIII al XIV, la fortaleza de Calatrava la Nueva y fijar su residencia en un palacio levantado a tal efecto en Almagro [figura $\mathbf{n}^{\circ}$ 6]. La transformación se constata también en un buen número de encomiendas del Campo de Calatrava: Calatrava la Vieja, Caracuel, Daimiel, Herrera, Mestanza, Villarrubia y tal vez Mudela. En el caso de Villarrubia la antigua fortaleza se transforma en casa de la encomienda. En Almoguera, el castillo fue destruido durante la sublevación del comendador mayor Juan Ramírez de Guzmán y la residencia comendataria se localizaba en la calle de la Encomienda de la villa. En Berninches, la vivienda perteneciente a la encomienda estaba junto a una torre que sobrevivía de la antigua fortaleza, mientras los castillos de Zorita, Aceca, Recena y Lopera fueron abandonados por los comendadores respectivos que en su lugar prefirieron casas comendatarias.

El proceso, iniciado en el transcurso del siglo XIV, parece consumado en la segunda mitad del siglo XV, cuando sólo en contadas excepciones los comendadores continúan residiendo en fortalezas, convenientemente acondicionadas

71 No existe un estudio monográfico de las casas de la encomienda calatravas, pero algunos datos que se conocen y las investigaciones sobre la arquitectura de otras órdenes militares permiten provisionalmente reseñar las características apuntadas. Vid. PÉrEZ MONZÓN, O.: «El Arte y las Órdenes Militares»: CAMPOS Y FERNÁNDEZ DE SEvilla, J.: (coord.), Lux Hispaniorum. Estudios sobre las Órdenes Militares, Madrid, 1999, 205-236, pp. 231-232.

72 Solano Ruiz, La Orden de Calatrava en el siglo XV, pp. 227 y 233. 
según los nuevos gustos nobiliarios y un sentido básicamente residencial, mientras que la mayoría de los caballeros calatravos las han sustituido por cómodas residencias palaciegas ${ }^{73}$, que en ocasiones cuentan con elementos lúdicos y recreativos. Tal es el caso de la casa de Argamasilla, con un buerto bien tratado para recreación, de la de Corral de Caracuel, con un vergel poblado por naranjos, árboles y rosas y un estanque con peces ${ }^{74}$, o de los palacios maestrales de $\mathrm{Al}$ magro, con un "corral de los çiervos», que para Villegas supone la conversión del edificio en una residencia nobiliaria particular ${ }^{75}$.

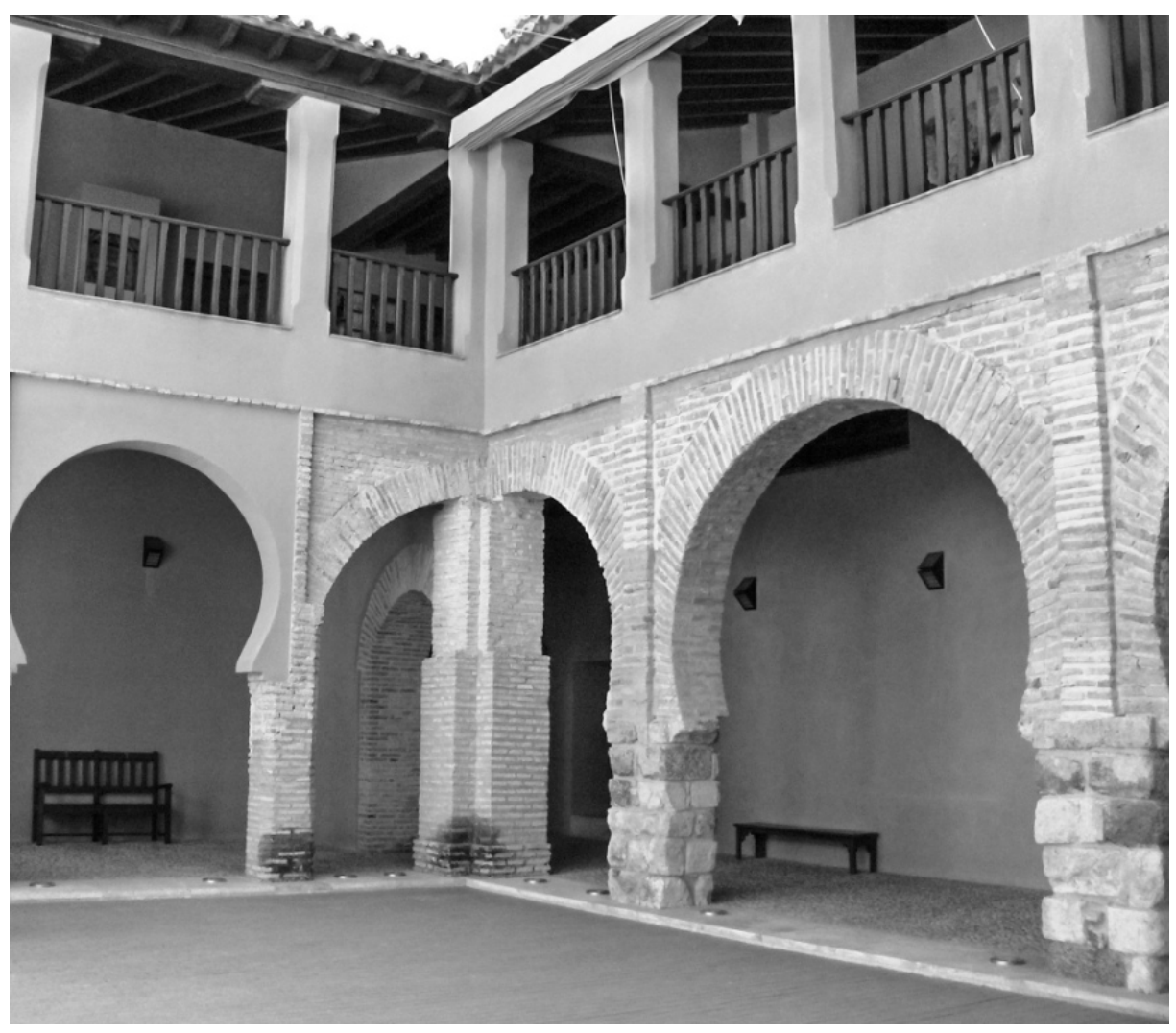

Figura $n^{\circ}$ 6. Patio del palacio maestral de Almagro (Ciudad Real).

73 Rodríguez-Picavea Matilla, E.: «Fortalezas y organización territorial en el Campo de Calatrava (siglos XII-XV)»: Actas do Simpósio Internacional sobre Castelos. Mil anos de fortificaçoes na Península Ibérica e no Magreb (500-1500), Lisboa, 2001, 623-632, pp. 628-629; Solano RuIZ, La Orden de Calatrava en el siglo XV, pp. 189-294.

74 AHN, OO.MM.: leg. 6080, n 6, fol. 3r y leg. 6078, no 20, fol. 201v.

75 Villegas DíAz, L.R.: Paisaje urbano con figuras. Almagro, Edad Media, Granada, 2003, p. 86. 


\section{LA IDEA DE LA FAMA Y LA PERDURACIÓN POST MORTEM}

La iglesia del sacro convento de Calatrava la Nueva, concluida en los años centrales del siglo XIII ${ }^{76}$, fue empleada desde tempranas fechas como ámbito funerario [figura $\mathbf{n}^{\circ} 7$ ]. Así en la nave de la epístola se enterró el magnate leonés Rodrigo Fernández fallecido en 1246 y el infante Alfonso de Mesa, hermano de Fernando III ${ }^{77}$. A estas sepulturas-lápida, desde finales del siglo XIV, sucedió la construcción de capillas funerarias que ocuparon la zona absidial y alteraron el perímetro templario, especialmente, el lado del evangelio pues la situación meridional del claustro limitó claramente el hastial de la epístola.

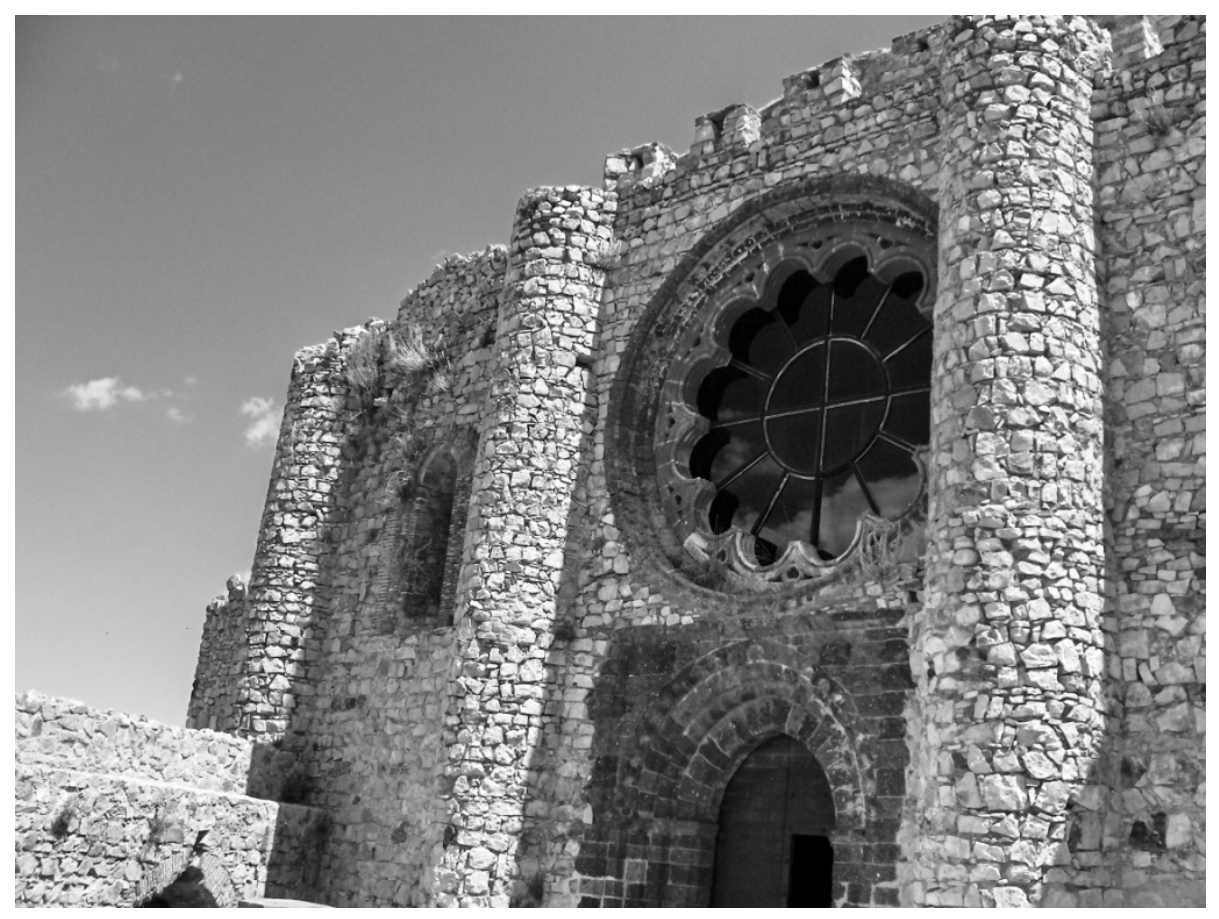

Figura $\mathrm{n}^{0}$ 7. Exterior de la iglesia del sacroconvento de Calatrava La Nueva (Aldea del Rey, Ciudad Real).

76 Momplet Mínguez, A.E.: «La iglesia del sacro castillo-convento de Calatrava la Nueva»: Homenaje al profesor Dr. D. José María de Azcárate y Ristori. Anales de Historia del Arte, 1993-1994, vol. 4, p. 181.

77 Nada queda ya de las sepulturas de la iglesia calatrava, pero conocemos los detalles por una descripción de 1644. Vid. COTTA y MÁrQuez Del PRADO, «Descripción del Sacro Convento y Castillo de Calatrava la Nueva», pp. 40-41. En adelante, y mientras no se indique lo contrario, la información sobre la morfología de las capillas y sepulcros procede de esta fuente. 
Detendremos nuestra atención en estas últimas como expresión de promoción artística, símbolo de una idea de la fama estrechamente ligada a la perduración post mortem y vehículo de exhibición del linaje y del poder ostentado. Como el resto de la nobleza de su tiempo, los calatravos proyectan su poder y su dignidad al porvenir mediante impactantes sepulcros funerarios ${ }^{78}$.

\subsection{La capilla funeraria de Gonzalo Núñez de Guzmán}

El primer maestre del linaje Guzmán, Gonzalo Núñez de Guzmán (13851404), eligió como ámbito de sepultura el lado de la epístola de la iglesia calatrava. La capilla estaba situada en el ábside meridional ${ }^{79}$ [figura $n^{\circ} 8$ ].

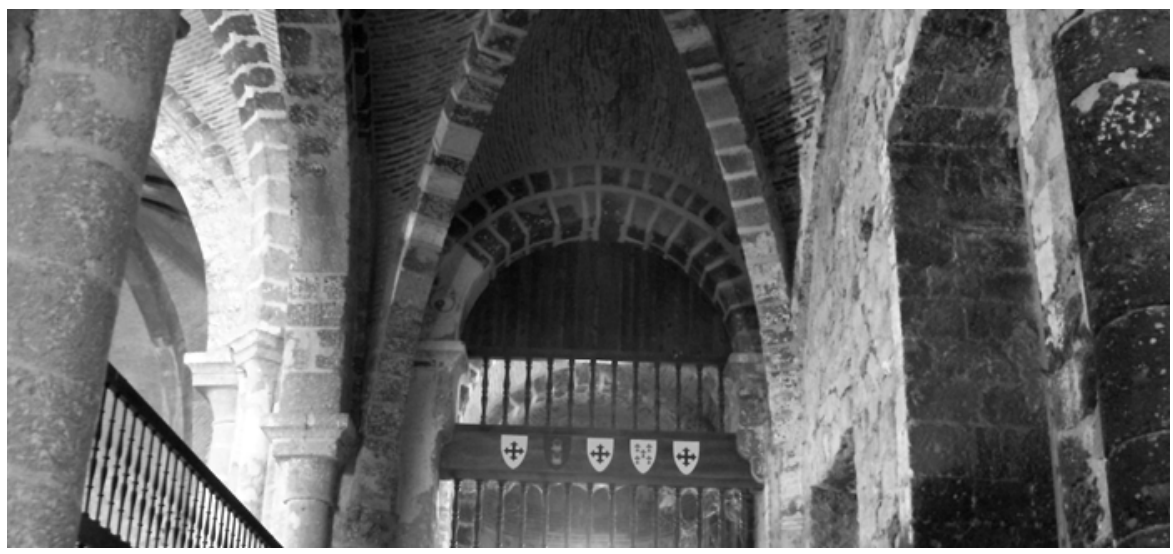

Figura no 8. Arco de entrada a la capilla del maestre Gonzalo Núñez de Guzmán en la iglesia del sacroconvento de Calatrava La Nueva.

El maestre ornamentó la capilla con escudos calatravos y con otros privativos de su persona y linaje ${ }^{80}$. La capilla, además, estaba adornada con pinturas

78 El deterioro e incluso total desaparición de estos ámbitos fúnebres está íntimamente relacionado con el abandono del convento en 1802 y el traslado de su comunidad a Almagro. Vid. CoRCHADO Soriano, M.: «Traslado y supresión del Sacro Convento de Calatrava»: Cuadernos de Estudios Manchegos, 5 (1974) 203-271.

79 Cotta y Márquez del Prado, Descripción del Sacro Convento, pp. 40-42. En cambio Cortés Arrese sitúa la capilla en el hastial propiamente dicho. Vid. CORTÉs ARRESE, M.A.: El espacio de la muerte y las Órdenes Militares, Cuenca, 1999, p. 145. La observación de los restos actuales del edificio, junto al testimonio de mediados del siglo XVII, permite inclinarse por la ubicación de la capilla en el ábside meridional.

${ }^{80}$ En 1583 la capilla se encontraba en buen estado [AHN, OO.MM.: Archivo Judicial de Toledo, leg, 42436, fol. 3]. 
conforme a una práctica característica del medievo. Nada prácticamente queda de ellas y, a mediados del siglo XVII, su deterioro impedía la lectura iconográfica de las mismas.

El sepulcro alabastrino, elevado sobre leones, ocupaba el centro de la estancia. En las paredes del mismo figuraban dos escudos de Calatrava, dos de armiños y dos de calderas, que remitían así a las armas propias y a las de su linaje. El yacente mantenía la tradición del animal simbólico a los pies - el perro como atributo de la fidelidad, el elemento militar —espada - y usos cortesanos - guantes y capilleta. En la cornisa aparecía la inscripción alusiva al maestre calatravo. El ajuar litúrgico de la capilla participa de estos mismos planteamientos. Citamos, siguiendo el inventario de 1495, un par de cálices de plata con sus patenas e sus armas en los esmaltes y una naveta e cuchara de plata senalada de sus armas ${ }^{81}$.

En 1397 el maestre dotó cinco capellanías para su capilla funeraria con las rentas de la dehesa del Retazo, situada en el Campo de Calatrava: para la capilla do está la nuestra sepultura, que nos agora havemos fecho en el dicho convento. Es decir, que siete años antes de la muerte del maestre la capilla y el sepulcro parece que ya estaban terminados. El maestre disponía además que estas dichas cinco capellanías, que se canten cada día por nuestras animas, et de los maestres, e freyles passados e de los que después de nos vernán. Et que estas rentas de esta dicha dehessa, que las hayan los freyles de missa del dicho convento en común, para que canten, e sirvan las dichas cinco capellanías, demás de las que en el dicho convento se cantan oy día ${ }^{82}$.

Se trata del primer paso en la conquista de la iglesia como espacio funerario privilegiado para los maestres. Hasta entonces el lugar sólo había sido utilizado en el siglo XIII por familiares de la Orden pertenecientes a la alta nobleza como el infante Alfonso de Mesa y el ricohombre leonés Rodrigo Fernández. A partir de ese momento, los restos mortales de todos los maestres calatravos que murieron en el ejercicio de su cargo fueron depositados en la iglesia del convento-fortaleza. Resulta significativo que el iniciador del proceso fuera Gonzalo Núñez de Guzmán, cuya etapa marca un hito en el proceso aristocratizador de la Orden de Calatrava. Materialización importante del poder alcanzado por este maestre fue la introducción de destacados miembros de su linaje en las principales encomiendas calatravas, incluyendo al que probablemente era su hijo, Luis González de Guzmán, que ocupó la encomienda mayor. Una muestra añadida del poder ostentado por Gonzalo Núñez de Guzmán es la concesión, obtenida del papa en octubre de 1401, de las encomiendas de Alcañiz y Peñarroya, tras la obligada renuncia de sus titulares respectivos, Guillén Remón y Benito de Mora, en beneficio del maestre ${ }^{83}$.

\footnotetext{
81 AHN, OO.MM.: leg. 6109, no 29, fol. 177 v.

82 Publ. Ortega y Cotes, Álvarez de Baquedano y Ortega Zúñiga y Aranda, Bullarium Ordinis Militiae de Calatrava, pp. 224-227.

83 AHN, OO.MM.: Calatrava, carp. 466, $\mathrm{n}^{\circ} 282$.
} 


\subsection{La capilla funeraria de Pedro Girón}

El poder de Pedro Girón se refleja en la magnificencia de sus empresas artísticas. En el palacio maestral de Almagro sufragó importantes reformas y en la iglesia conventual de Calatrava la Nueva una de las más espléndidas capillas funerarias del siglo XV [figura $\mathbf{n}^{\circ}$ 9]. Ambas obras emplearon como ornato, de forma reiterativa, la cruz de Calatrava y las armas de Pedro Girón: "cortado encajado de oro y gules; jefe partido de Castilla y León» ${ }^{84}$ [figura $\mathbf{n}^{\mathbf{0}} 10$ ]. Según la descripción de 1644, sus armas decoraban el arco de acceso a la capilla, la bóveda — sostenida, probablemente con claves de ángeles tenantes - el sepulcro e incluso una imagen mariana de devoción ${ }^{85}$. El aspecto no debía de ser muy diferente salvando las diferencias en el tamaño, al que ofrece la capilla del maestre santiaguista Álvaro de Luna en la girola de la catedral de Toledo, construida hacia 1435 por el maestro Hanequín de Bruselas y convertida en una referencia básica de las obras tumulares tardogóticas ${ }^{86}$.

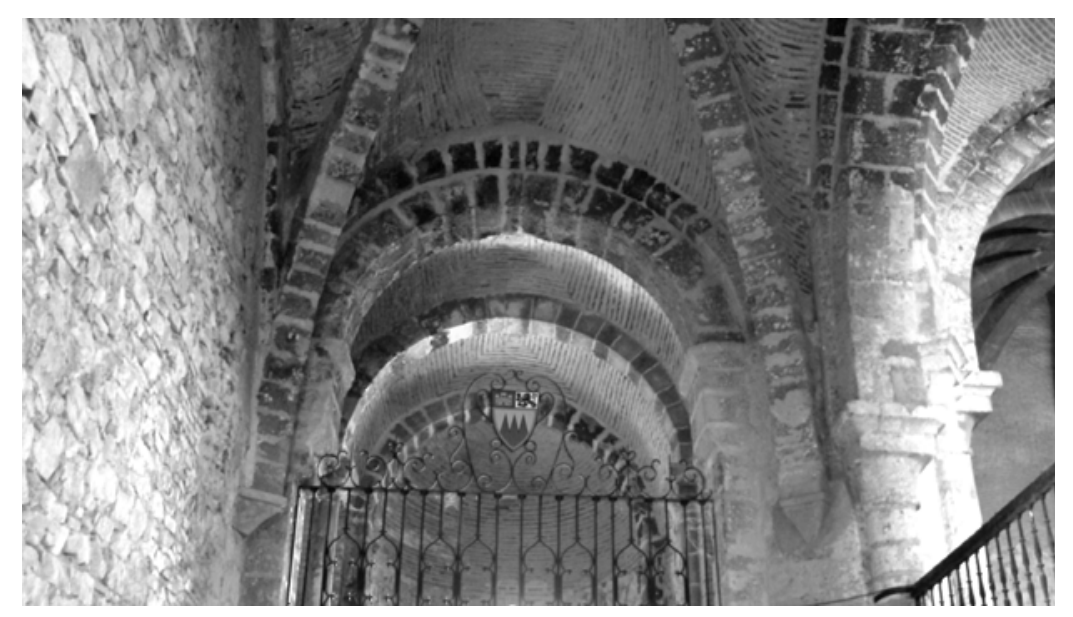

Figura no 9. Capilla del maestre Pedro Girón en la iglesia del sacroconvento de Calatrava La Nueva.

La capilla de Girón coincide con el ámbito fúnebre de los Luna en su ubicación privilegiada —el ábside norte ${ }^{87}$ - en su cubrición abovedada que poten-

84 Pardo de Guevara, F.: Manual de Heráldica Española, Madrid, 1987, p. 92.

85 Vid. COTTA y MÁrquez Del PRADO, «Descripción del Sacro Convento y castillo de Calatrava la Nueva», pp. 43-44.

86 YARZA LUACES, La nobleza ante el rey, p. 134.

${ }_{87} \mathrm{La}$ idea de la jerarquización del espacio funerario en el ámbito arquitectónico está muy presente en un conocido trabajo de BANGO TORVISO, I.G.: «El espacio para enterramientos privilegia- 
cia la tipología centralizada y en el empleo de materiales de calidad. La citada descripción del siglo XVII la considera una obra de alabastro. A falta de estudios que arrojen claridad sobre este aspecto, pensamos que el término se emplea con sentido metonímico y corresponde su utilización a partes concretas como la solería ${ }^{88}$, quizá un zócalo, el sepulcro propiamente dicho y determinadas piezas litúrgicas. La visita de 1495 cita de forma expresa un tabernáculo de alabastro y una imagen de alabastro que está en su capilla ${ }^{89}$.

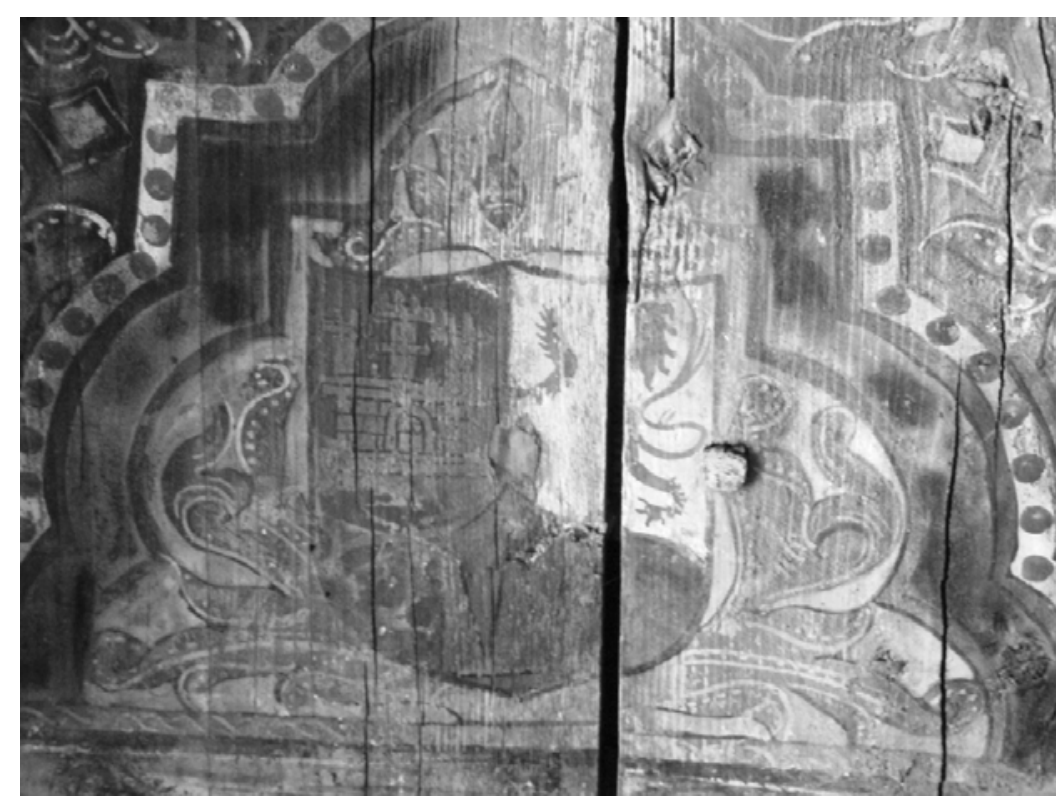

Figura $\mathrm{n}^{\circ}$ 10. Armas del maestre Pedro Girón en la planta superior del patio del palacio maestral de Almagro.

Menos incertidumbres plantea la autoría de la obra arquitectónica gracias al testamento de Pedro Girón, redactado el 28 de abril de 1466 en Villarrubia, lugar en que moriría el 2 de mayo de ese año:

...mando que mi cuerpo sea sepultado en el convento de mi horden en la forma e manera que las reglas e difiniçiones de aquella lo permiten e mandan. E que sea se-

dos en la arquitectura medieval española»: Anuario del Departamento de Historia y Teoría del Arte, 1992, vol. IV, 93-132, especialmente p. 114 y ss. También se refiere a la jerarquización espacial aplicada a la iglesia de Calatrava la Nueva CORTÉs ARRESE, El espacio de la muerte y el arte de las órdenes militares, pp. 127-158.

88 Según la citada visita de 1644 , el suelo estaba cubierto de pequeñas losas blancas y negras.

89 AHN, OO.MM.: leg. 6109, n 29, fol. 178. 
pultado en la capilla que yo mandé fazer en la yglesia del dicho convento, la qual mando que se faga e acabe por la vía e manera que yo lo tengo hordenado e ygualado con maestre Haniquin, de que está razón en los libros de mi fazienda...Item mando que sean fechas mis honrras segund se acostunbran fazer a los maestres que antes de mi fueron e como mejor e más conplidamente se deuiere o pudiere fazer ${ }^{90}$.

La elección de Hanequín de Bruselas como el artífice de la capilla de Pedro Girón no debe de pasar desapercibida. Este artista flamenco llegó entre 14301435 al reino castellano acompañado de un equipo de arquitectos, entalladores y escultores, entre los que se encontraba su hermano Egas Cueman, y consiguió ser maestro mayor de la catedral de Toledo ${ }^{91}$. En cualquier caso, cuando Pedro Girón le encarga su capilla funeraria, el maestro Hanequín de Bruselas se encuentra en el cenit de su carrera artística. El noble calatravo en su intento de representar su poder post mortem y transmitir su memoria busca lo mejor entre lo que puede encontrarse en la Castilla del momento. La decisión indica hasta que punto Girón valoraba la fama y la transmisión de una cuidada imagen para la posteridad. Su modelo se seguirá en las capillas del Condestable en la catedral de Burgos y de los Vélez en el templo catedralicio murciano.

La obra tumular mantiene el tradicional formato de paralelepípedo exento con yacente en la tapa ataviado con el traje maestral, espada y un perro a los pies como atributo de fidelidad ${ }^{92}$. El sepulcro, se mantiene poco receptivo a las novedades iconográficas concretadas en la segunda mitad del siglo XV, léase el empleo de la pose orante en el difunto o la sustitución del animal acompañante por un paje/servidor que manifiesta en su actitud afligida la tristeza por el óbito.

La originalidad del cenotafio estriba en el ornato de sus paredes con el cincelado de freires calatravos en los encasamentos laterales. José María de Azcárate, basándose en la descripción de 1644, relacionó esta imagen con la tumba de Felipe el Atrevido en Dijon, obra de Sluter y planteó la autoría de Egas Cueman ${ }^{93}$. Mas el documento mencionado no precisa el gesto de los frailes - ¿plorantes?_- , sólo las cartelas que portan y permiten la identificación de

90 Casado Quintanilla, Corona de Castilla: Documentos de la Orden de Calatrava, p. 296.

91 En la catedral realizó obras de gran riqueza ornamental. Autor además de la girola de la catedral de Cuenca, es posible que trabajara también en el castillo de Escalona al servicio de Álvaro de Luna. Vid. Azcárate, J.M ${ }^{\mathrm{a}}$, «El maestro Hanequin de Bruselas»: Archivo Español de Arte, XXI (1948) 173-188; y AzCÁRATe, J.Ma , Arte gótico en España, Madrid, 1990, pp. 116-117.

92 En 1583 la capilla y el bulto del maestre estaban buenos e bien reparados. En el mismo estado se hallaba una arquita con los huesos de Rodrigo Telléz Girón (AHN, OO.MM.: leg. 42436, Visitación al Sacro Convento, fol. 2 v).

93 Artífice que, según este autor, pudo intervenir también en las tumbas de los padres y abuelos de Pedro Girón en la colegiata de Belmonte (AzCÁRATe, Arte gótico en España, p. 245). Recientemente, Teresa Pérez Higuera ha respaldado la posible participación del maestro Egas en el cenotafio (PÉREZ Higuera, T.: «El foco toledano y su entorno»: Actas del Congreso Internacional sobre Gil Siloe y la escultura de su época, Burgos, 2001, 263-286, p. 272). 
Fadrique de Acuña, comendador de Zorita ${ }^{94}$, y Gonzalo de Cuello, comendador de Alcolea, Benavente y Almadén ${ }^{95}$.

Desde las Partidas de Alfonso X el Sabio, donde se cita la procesión de hombres ilustres como una muestra de honor al monarca fallecido, las comitivas fúnebres de carácter cívico-religioso han constituido un ornato frecuente en los monumentos tumulares. Recordemos, en este sentido, el sepulcro del infante don Felipe en Villalcázar de Sirga (siglo XIII) o el de la abadesa de Cañas (siglo XIV). El cenotafio de Girón participa de esa tradición con la metamorfosis que supone la inserción en las comitivas de personajes reales y coetáneos al finado. En un período de tendencia a la individualidad y al nominalismo, la presencia de comendadores calatravos con nombres propios constituye una rúbrica visual de la lauda encomiástica escrita en la tapa sepulcral:

Aquí yace el Muy Magnifico y muy Virtuosso Senor el noble don Po Jirón, Maestre de la cavalleria de la orden de calatrava, Camarero Mayor del Rey de Castilla y Leon y del su Consexo, el qual, en veynte años que fue Maestre, en mucha prosperidad esta orden rigió, defendió y acrecentó en muy gran puxança. desta pres ${ }^{\text {te }}$. vida ffalleçió a dos días de Mayo Anno del Sr. M.CCCC.LX.VI ${ }^{96}$.

Lo más sorprendente del sepulcro, no obstante, eran las figuras angélicas angulares, que en pleitesía permanente, sostenían los escudos maestrales. La originalidad iconográfica permite relacionarlo con los trazas que Sebastián de Toledo - Sebastián de Almonacid- realizó por encargo de la duquesa del Infantado para los sepulcros de Álvaro de Luna y de su mujer Juana de Pimentel ${ }^{97}$. La cronología más avanzada de estos últimos posibilita un paso más en el proceso de «insolencia» nobiliaria al sustituir los ángeles por caballeros santiaguistas de gesto melancólico en permanente genuflexión ${ }^{98}$. En esta misma línea, la tipología del sepulcro de Girón debe situarse en la pugna mantenida en el siglo XV por conseguir el sepulcro más original y espectacular. Sin embargo, siguiendo los planteamientos de Joaquín Yarza, el modelo yacente es conservador, ya que en ese momento empieza a triunfar la más innovadora figura del difunto orante. Precisamente, hacia 1467, es Egas Cueman el responsable de uno de los primeros ensayos de esta nueva concepción, que es algo más que un

94 Casado Quintanilla, Corona de Castilla: Documentos de la Orden de Calatrava, n 13,19 y 20.

95 Casado Quintanilla, Corona de Castilla: Documentos de la Orden de Calatrava, ${ }^{\circ}$ 19, 20, 25 , 26 y 29.

96 Cotta y Márquez Del PRAdo, «Descripción del Sacro Convento y castillo de Calatrava la Nueva», pp. 43-44.

97 La idea ya fue apuntada por Teresa Pérez Higuera que, asimismo, recuerda la fama que alcanzó la figura yacente de Girón convertida en modelo para el sepulcro de Fernando de Córdoba contratado por Alonso de Covarrubias en 1555 (PÉREZ HigUeRA, «El foco toledano y su entorno», p. 272).

98 La premeditada presencia de caballeros santiaguistas contrasta con la colocación en el sepulcro de Juana Pimentel de religiosos franciscanos en las esquinas tumulares. 
mero cambio formal99, cuya primera manifestación hispánica corresponde a la estatua orante del obispo Lope Barrientos, fechada a mediados del siglo XV ${ }^{100}$.

El ajuar litúrgico de la capilla Girón participa de los mismos criterios esbozados. La heráldica maestral figuraba en unos collares de damasco morados, en diversas vestimentas litúrgicas y en útiles de plata como un calice dorado e un par de candeleros dorados e un par de ampollas doradas senaladas de la borden e de sus armas ${ }^{101}$.

Pedro Girón se ocupó además de asegurar el servicio litúrgico de la capilla. Los freires del convento de Calatrava la Nueva recibieron 10.000 maravedís de juro de heredad situados por salvado en la ciudad de Córdoba, a cambio de oraciones, la celebración de una misa diaria en la capilla y el responso sobre la sepultura. Las misas debían decirse de la siguiente manera: los días de lunes una misa cantada de requiem con su responso; e los días de los sábados otra misa cantada del ofiçio de nuestra señora la Virgen María en quien yo tengo deuoçión; e los otros días, cada día, vna misa rezada...encargando a los dichos freyles çerca de esto sus conçiençias. Más adelante el maestre calatravo indicaba que al prior y freires de su convento de Calatrava les entregaran 30.000 maravedís para asegurar el rezo por su alma.

Pedro Girón también reguló sus funerales. En una cláusula testamentaria, encargaba que el día de su entierro se dijeran 60 misas en su memoria recompensando a cada oficiante con una limosna de diez maravedís. A ello había que sumar los cinco treintanarios que debían decirse por su alma en los monasterios de San Francisco de Úbeda, la Sisla de Toledo, La Cabrera, San Francisco de Peñafiel y Olmedilla, además de los 15 treintenarios por sus difuntos padres que dejaba comisionados en la iglesia de la villa de Belmonte. Asimismo, dispuso el oficio de dos vigilias anuales y misas segund e tan conplidamente como se suele dezir por los otros maestres, e que se digan más dosçientas misas en los logares que entendieren mis testamentarios y la realización de alhajas adecuadas para estos usos litúrgicos:

Iten mando que se fagan para la dicha mi capilla tres casullas: la vna, de tapete negro, e sirua los lunes; e la otra, de seda blanca, que sirua los sábados; e la otra, de tapete verde, e sirva los otros días de la semana. E así mesmo que sea de lienço e otras cosas que fueren menester para almátycas e otros enderesços de las dichas capillas e para la dicha capilla, lo qual se faga a disposiçión de los dichos mis testamentarios.

99 YARZA LUACES, «La imagen del rey y la imagen del noble en el siglo XV», pp. 285-286.

${ }^{100}$ Ya se menciona en el testamento redactado por este obispo conquense el 17 de noviembre de 1454, aunque la cabeza pudo ser de factura posterior. Dado el trabajo preciosista del alabastro, su autoría se relaciona con el círculo de escultores que trabajaban en Toledo. Tal vez se trate del entorno de Hanequín de Bruselas y no es descartable que el autor material de la escultura fuera el propio Egas Cueman. Se encarga de resumir las posturas sobre el particular ARA GIL, C.J.: «Fray Lope de Barrientos»: Museo de las Ferias, 2004. Comercio, mercado y economía en tiempos de la reina Isabel, Valladolid, 2004, 102-105.

101 AHN, OO.MM.: leg. 6109, nº 29, fol. 178. 
Iten mando treynta marcos de la mi plata que yo traygo de contino para que se fagan dos cálizes e dos candeleros e una cruz e vn par de binageras para la dicha capilla, lo qual todo se faga a disposiçión de los dichos mis testamentarios ${ }^{102}$.

$\mathrm{Al}$ parecer, todo se hizo siguiendo las instrucciones del maestre Girón, ya que el 1 de junio de 1466, el capítulo de la Orden de Calatrava reunido en Almagro comunicó al concejo de Murcia que fue leuado su cuerpo a la sepultura con aquella honor e reuerençia que podimos ${ }^{103}$. Probablemente, la tutela ejercida por el poderoso marqués de Villena, hermano del fallecido, no permitía otra alternativa.

Para contextualizar adecuadamente esta exhibición de recursos es conveniente recordar que Pedro Girón acumuló uno de los más importantes patrimonios nobiliarios de su tiempo, que comprendía, entre otras cosas, los señoríos de Urueña, Tiedra, Peñafiel, Villamayor, Villafrecho, Gumiel de Izán, Santibáñez, Osuna, Morón, Gelves, Olvera, Ortegícar y Archidona; las tenencias de Carrioncillo y Montes de Rebollar y, coyunturalmente, de la ciudad de Toledo; las tercias de Arévalo; y la justicia y las rentas de los cambios de la feria de Medina del Campo ${ }^{104}$. Con este impresionante patrimonio, el maestre calatravo consiguió fundar un mayorazgo, para su hijo Alfonso Téllez Girón, que llevaría el título de conde de Urueña. Al morir sin descendencia traspasó los derechos a su hermano Juan ${ }^{105}$. Además el poder de Pedro Girón en el interior de la Orden fue incrementándose ${ }^{106}$, particularmente a partir del acceso de Enrique IV al trono de Castilla en 1454. Testimonios reveladores de este poder y del ambicioso comportamiento del maestre fueron la disposición de patrimonio calatravo en función de sus intereses personales mediante la permuta de la villa de Osuna y el castillo de Cazalla por las villas de Fuenteovejuna y

102 Casado Quintanilla, Corona de Castilla: Documentos de la Orden de Calatrava, no 21, pp. 296298. El testamento de Pedro Girón había sido publicado anteriormente por UHAGÓN, F.: Órdenes militares. Discursos leídos ante la Real Academia de la Historia, Madrid, 1898, $\mathrm{n}^{\circ}$ IX, pp. 84-94; VIÑA Brito, A.: «Testamento de don Pedro Girón»: Anuario de Estudios Medievales, 19 (1989) 493-505.

${ }_{103}$ Publ. Torres SuÁRez, C.: «Don Rodrigo Téllez Girón, maestre de Calatrava»: Anuario de Estudios Medievales, 11 (1981) 775-792, doc. 2; CASADo QuinTAnilla, Corona de Castilla: Documentos de la Orden de Calatrava, $\mathrm{n}^{\circ} 23$.

104 CABrera, E. y Moros, A.: Fuenteovejuna. La violencia antiseñorial en el siglo XV, Barcelona, 1991, p. 105.

105 Aguado GonZÁLEZ, F.J.: El ascenso de un linaje castellano en la segunda mitad del siglo XV: los Téllez Girón, condes de Urueña (el origen del señorío de Osuna), 2 vols.: Madrid, 1991; Franco, SiLva, A.: «Don Pedro Girón, fundador de la Casa de Osuna (1423-1466)»: Osuna entre los tiempos medievales y modernos (siglos XIII-XVIII), Sevilla, 1995, 63-93 (reeditado en su libro Señores y señoríos, Jaén, 1997, 217-260); y Viña BRito, A.: Don Pedro Girón, maestre de Calatrava, y los orígenes de la Casa de Osuna, Tesis Doctoral, Universidad de Sevilla, 1986 (microfichas, Barcelona, 1988).

106 O'Callaghan, J.: «Don Pedro Girón, Master of the Order of Calatrava, 1445-1446»: Hispania, 21 (1961), 342-392 (reimpresión en su libro The Spanish Military Order of Calatrava and its Affiliates, Londres, 1975, VIII); UHAGÓN, Órdenes militares, pp. 12-34; VAL VALDIVIESO, Ma I. DEL, «Relaciones de Don Pedro Girón, maestre de Calatrava, con el rey Don Enrique IV». En VII Centenario del infante don Fernando de la Cerda, Ciudad Real, 1976, 159-170. 
Bélmez ${ }^{107}$, y la designación como su sucesor al frente del maestrazgo de su hijo Rodrigo Téllez Girón, caso excepcional y sin precedentes en la historia calatrava que atentaba contra todos los estatutos de la Orden por tratarse además de un menor de edad sin el hábito calatravo.

\subsection{Otros sepulcros maestrales}

Los sepulcros de otros maestres situados en la iglesia del sacro convento de Calatrava la Nueva ${ }^{108}$ reproducen a menor escala las mismas pretensiones mencionadas para las capillas. Desde luego no se puede tildar de enterramiento modesto el dispuesto para el maestre Luis González de Guzmán, situado en el centro de la capilla mayor, el más privilegiado de cuantos espacios puedan encontrarse, aunque de su sepulcro sólo sabemos que era de piedra negra, contaba con epitafio y tenía tres escudos con dos calderas cada uno, armas propias de los Guzmán, pero sin los armiños que se exhibían en la capilla de su antecesor Gonzalo Núñez de Guzmán.

Tampoco es despreciable el emplazamiento, debajo de la grada de la capilla mayor y entre los dos coros, de los enterramientos de Fernando de Padilla y de su hermano García López de Padilla. El del maestre electo era de piedra negra y exhibía tres escudos con tres padillas cada uno, mientras que el del último maestre calatravo era de alabastro con epitafio y dos escudos, uno con las tres padillas y el otro con 13 roeles.

En cambio, Rodrigo Téllez Girón no contó con un enterramiento acorde con el de los maestres del siglo XV. Sus restos estaban en una caja pequeña de madera, cubierta con terciopelo negro. Esta caja permaneció sobre unas sillas de la capilla mayor hasta 1577 , cuando fue trasladada a la capilla de su padre. A mediados del siglo XVII aparecía ya muy deteriorada.

\subsection{Los comendadores mayores entran en escena}

Sólo cuando el maestrazgo pasó a ser administrado por la Corona, los comendadores mayores, máxima dignidad a la que podía llegar un freire calatravo a partir de entonces, pudieron levantar capillas funerarias en la iglesia conventual similares a las erigidas por los maestres. Sin embargo, quedaron excluidos del espacio privilegiado de la cabecera, ámbito funerario reservado en exclusiva a los maestres de la Orden.

107 Ya en 1461 hubo un primer intento fallido de permutar Osuna y Cazalla por otros lugares del marquesado de Villena. Vid. AHN, OO.MM.: Calatrava, carp. 450, $\mathrm{n}^{\circ} 137$.

108 Se ha ocupado también de los ámbitos funerarios en Calatrava la Nueva CORTÉs ARRESE, El espacio de la muerte y el arte de las órdenes militares, pp. 140-158. Se basa fundamentalmente en la descripción del siglo XVII publicada por Cotta y Marquéz de Prado. 
Muy poco después del fallecimiento en 1489 del último maestre García López de Padilla, el comendador mayor Diego García de Castrillo decidió levantar su propia capilla funeraria. El 15 de septiembre de 1493 las obras habían concluido. En la «revolucionaria» decisión debió influir no poco su condición de Administrador del maestrazgo de la Orden de Calatrava en paz y en guerra en lugar del último maestre... adonde se ve el estandarte de la orden en testimonio de la auctoridad y poder de maestre, que figuraba en la larga y laudatoria inscripción de su capilla, que aludía también a la antigüedad del linaje leonés de Castrillo, al carácter valeroso del comendador mayor y a su eficacia en la lucha contra los musulmanes ${ }^{109}$.

El emplazamiento elegido fue el muro del evangelio, a los pies de la iglesia y en la parte más alejada de la cabecera. Tal vez no se atrevió a situarla más allá, al ser el primer comendador mayor en utilizar tan privilegiado espacio funerario que, secundando la práctica anteriormente descrita, adornó con las armas propias de su linaje. El promotor de la obra permitió que, al margen de sus posibles herederos, en ella se enterrase también el clavero calatravo Ramiro Núñez de Guzmán, por lo mucho que le amó y estimó y por mucho amor que le tenia de le dar este enterramiento igual del suy $0^{110}$. De tal suerte que se convertía así en el primer clavero de la Orden en disfrutar de eterno descanso en el privilegiado espacio de la iglesia conventual ${ }^{111}$.

109 COTTA y MÁrQuez del Prado, «Descripción del Sacro Convento y Castillo de Calatrava la Nueva», pp. 58-59. La inscripción completa era la siguiente: Alabuena memoria del sr. don frey Diego garcia de castrillo, cavallero leones de la cassa de castrillo tan antigua y fuerte $q^{e}$. por Tradición de aquella tierra se cree que resistió al orgullo y poder de los moros, el qual fué tan valeroso que llegó a ser Comendador $M^{o r}$. y Administrador del Maestrazgo de la orden de Calatra en paz y en guerra en lugar del último maestre, mereçio dignam ${ }^{t e}$. la gracia de los $S^{\text {es }}$. Reyes catholicos $D . F^{d o} y d^{a}$ Isabel assi porque con la auctoridad qu tenía en su orden dispuso mas suavem ${ }^{\text {te }}$ la incorporación del maestrazgo de Calatra en la corona Real, como porque habiendo sido su maestresala y capitan de trescientas lanças les asistio 35 años continuos sin soltar las armas de las manos en las guerras contra los moros asta que el dia que (sujeto el Reyno de Granada) se halló a poner los pendones de Santiago y Real en la Torre del omenaxe del Alhambra, dando en todas ocasiones exemplo rato de valor y prudencia a los suyos y de terror y admiración a los enemigos, como en aquella vatalla de las faldas de la sierra del madroño tan memorable q desde su tiempo quedó pa memoria de la posteridad escrita en la de todos por haber sido como Increible el estrago qu Hiço en la morisma él solo, siendo Alcayde de los Alcazares de Eçixa, por su mano, abriendo prim $q^{a}$ acometiesse cortado la piernas a su cavallo para animar y no parecer a su jente superior más $q^{e}$ en la grandeça de aquel ánimo qe tanto se aventaxo siempre en la exaltación de la ffee y nombre de los xpianos. y en el Rendim ${ }^{\text {to }}$ de la perfidia y fuerças de los moros. fué signular benefactor de su orden y de sus cavalleros cuyo sacro conv ${ }^{\text {to }}$ enrriqueció con la fábrica del choro q se acabó año de 1.492 y el de 1.493 con ésta capilla que quisso fuesse fiel deposito de su cuerpo asta la Resurrección universal y para el de sus herederos, permitiendo que solam ${ }^{t e}$ se enterrase en Ella en la forma q Él, Don frey Ramiro Nuñes de guzman, clavero de Calatrr', por lo mucho que le amó y estimo, adonde se vé el estandarte de la orden en testim ${ }^{\circ}$ de la auctoridad y poder de maestre con que en su vacante la administro. Sus herederos y sucesores renovaron y dotaron èsta capilla, año de 1.632.

110 CotTa Y MÁRQUeZ DEL PRADO, «Descripción del Sacro Convento y Castillo de Calatrava la Nueva», pp. 58-59.

${ }^{111}$ No consta documentalmente la elevación de capillas funerarias por parte de otros caballeros calatravos antes del siglo XVI. La noticia de la capilla levantada por el clavero García López de 
El material elegido para los sepulcros, la madera, contrasta con el alabastro de las tumbas maestrales y demuestra, pese a todo, las insalvables distancias, en una proporción aproximada de diez a uno, entre las rentas de las que disponían los maestres y las que podían percibir el comendador mayor o el clavero. Por otra parte, ambos sepulcros siguen un similar modelo iconográfico de yacente con espada, manto con cruz roja, perro a los pies, además de algunas labores en la madera, de oro sobre negro. El de Diego García de Castrillo exhibía la armas propias de su linaje, mientras que el del clavero Guzmán tenía escudos de las órdenes de Calatrava y Alcántara, y emblemas con calderas y armiños, propias también de otros miembros de su linaje.

El sucesor en la encomienda mayor de Diego García de Castrillo, Gutierre de Padilla ${ }^{112}$, da un paso más en la conquista de un espacio funerario hasta entonces reservado a los maestres y sitúa su capilla en la zona más cercana a la cabecera de la nave del evangelio. Levanta la mayor de las capillas de cuantas tenía y tendrá la iglesia calatrava, conocida después como «La Grande», por ser la más capaz; y por esta razón se dan en ella los hábitos a los Caballeros y Religiosos ${ }^{113}$. La capilla, protegida con una reja de hierro dorada, estaba adornada con las armas del comendador Padilla y un retablo escultórico dorado, con el Descendimiento de Cristo en su calle central y otras ocho tablas dedicadas a San Benito, San Bernardo y seis misterios. Las armas del comendador mayor remataban esta obra.

Sin embargo, Gutierre de Padilla no fue sepultado en «La Grande». Para su eterno descanso se escogió un espacio considerado más privilegiado: la capilla mayor del monasterio calatravo de la Asunción en Almagro, que había sido fundado con rentas dejadas por el comendador mayor. En la zona central de la capilla mayor se situaba su suntuoso sepulcro ${ }^{114}$, desaparecido en la actualidad y del que nada más conocemos ${ }^{115}$.

Padilla no parece verosímil, ya que las numerosas anomalías del documento hacen sospechar de su autenticidad. Vid. AHN, OO.MM.: sign. 1348c, fols. 120-122. Rebasada la barrera cronológica de 1500 los datos son más abundantes. Así nos encontramos con la capilla fundada por Francisco de Bobadilla, comendador de Auñón, junto a la capilla de Nuestra Señora de los Mártires en Calatrava la Nueva. En ella se enterraron el obrero Juan de Burgos, Juan de Valdelomar, comendador de El Viso, y probablemente Pedro de Torquemada, comendador de Lagunarrota. Vid. CoTTA Y MÁrQUEZ DEL PRADO, «Descripción del Sacro Convento y Castillo de Calatrava la Nueva», p. 63.

${ }_{112}$ El comendador mayor Gutierre de Padilla fue sobrino del último maestre calatravo García López de Padilla y no del comendador mayor García de Padilla, parentesco que le atribuye CoRTÉs ARRESE, El espacio de la muerte y el arte de las órdenes militares, p. 144.

113 En 1583, necesitaba reparo por tener hendiduras (AHN, OO.MM.: leg. 42436, fol. 2 v).

114 COTTA Y MÁRQUEZ DEL PRADO, «Descripción del Sacro Convento y Castillo de Calatrava la Nueva», pp. 46-47.

115 El sepulcro todavía se conservaba a mediados del siglo XVII, a pesar de lo que indica CoRTÉs ARRESE, El espacio de la muerte y el arte de las órdenes militares, p. 144. El error de este autor procede de considerar las notas a pie de página de la edición de la descripción de mediados del siglo XVII como de esa misma época, cuando en realidad son obra del editor Cotta. 


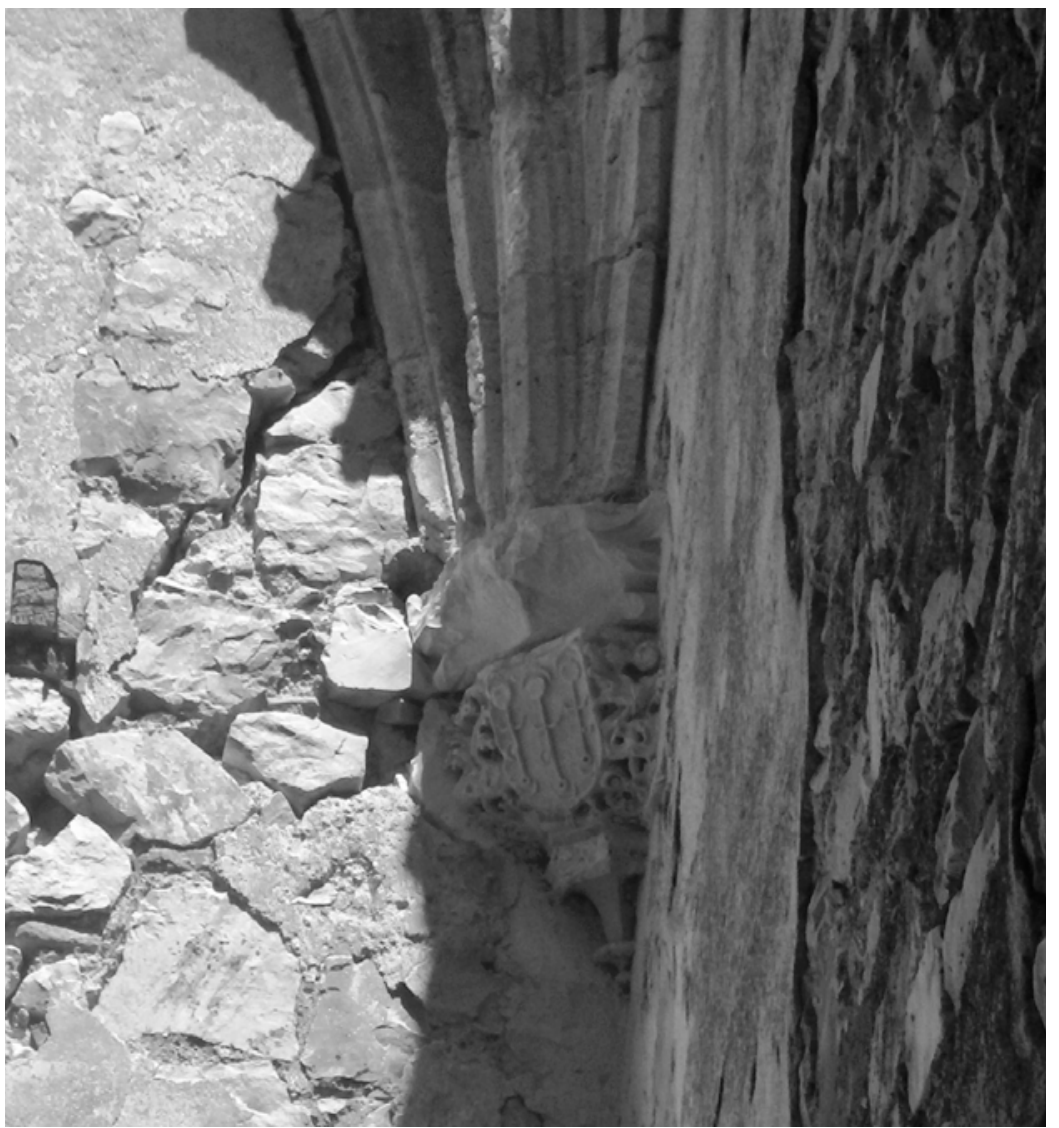

Figura $\mathrm{n}^{\circ}$ 11. Armas de los Padilla en la capilla del comendador mayor García de Padilla. Iglesia del sacroconvento de Calatrava La Nueva.

Finalmente, el comendador mayor García de Padilla (1523-1542) compró al comendador Francisco de Rojas una última capilla funeraria ${ }^{116}$. Se trata de la conocida como «Capilla Dorada», así dicha por estarlo toda, situada en la nave del evangelio, entre la sacristía y la capilla de Diego García de Castrillo. Se agotaba así el espacio funerario disponible para la construcción de capillas en la iglesia conventual. La capilla, que albergaba los restos de su propietario, contaba con un retablo pintado ${ }^{117}$ y debía ser de apariencia magnífica tal y como

116 RADes y ANDRADa, Chronica de Calatrava, fol. 85r.

${ }_{117}$ En 1583, se ordena reparar el retablo de este ámbito (AHN, OO.MM.: Archivo Judicial de Toledo, leg. 42436, fol. 2v). 
recordaban un siglo después: es vistosa Capilla y puede honrar cualquier casa ${ }^{118}$ [figura $\mathbf{n}^{\mathbf{0}} 11$ ]. Sin embargo, su cronología rebasa ampliamente el límite que nos hemos impuesto para este artículo.

En la iglesia calatrava se produjo una jerarquización del espacio funerario en beneficio de los maestres calatravos, los únicos personajes que pudieron enterrarse en la cabecera de la iglesia. Sólo cuando éstos desaparecieron, al asumir la administración del maestrazgo la Corona, los comendadores mayores pudieron utilizar la iglesia como ámbito funerario, aunque siempre en capillas abiertas en el lienzo de la nave del evangelio. Al resto de los freires de la Orden, les fue vedado el acceso a tan privilegiado espacio mortuorio. La primera de las excepciones está representada por el caso ya citado del clavero Ramiro Núñez de Guzmán. La segunda se refiere a la tumba, situada en medio del coro, de Gonzalo Fernández de Córdoba, obrero de Calatrava y comendador de Manzanares fallecido en $1545^{119}$.

\section{A MODO DE CONCLUSIÓN: LA NOBLEZA CALATRAVA Y EL ALCANCE REAL DE SUS ACTIVIDADES ARTÍSTICAS Y CULTURALES}

La mayor parte de las obras artísticas emprendidas por dignidades calatravas se localizan en el convento-fortaleza de Calatrava la Nueva y, de forma especial, en la iglesia por su valor simbólico y representativo. El ornato del templo no tuvo exclusivamente un carácter funerario. El maestre García López de Padilla promovió la construcción de la sacristía y el retablo mayor ${ }^{120}$. El comendador mayor Diego García de Castrillo ordenó levantar un claustro, o al menos una parte de él, y el coro que en 1492 ya estaba finalizado. Fuera del templo, el clavero Alonso de Silva elevó un humilladero de piedra muy bueno en medio del Campo de los Mártires; bajo la cruz del mismo, que es muy vistosa, dispuso su sepultura, de muy buena piedra y muchas labores y molduras.

El otro núcleo donde se concentró la promoción artística calatrava fue la villa de Almagro. En esta villa es necesario subrayar las sucesivas obras empren-

\footnotetext{
118 CotTa y MÁrqueZ Del Prado, «Descripción del Sacro Convento y Castillo de Calatrava la Nueva», pp. 54-57.

119 Vid. Cotta y Márquez del Prado, «Descripción del Sacro Convento y Castillo de Calatrava la Nueva», p. 39.

${ }^{120}$ Con la plata de Padilla, se realizó el relicario argénteo del altar mayor (AHN, OO.MM.: Archivo Judicial de Toledo, leg. 42436, fol. 2).
} 
didas en los palacios maestrales ${ }^{121}$ por los maestres de los linajes Guzmán, Girón y Padilla. Sobresale entre todas ellas la capilla de San Benito, lugar ya existente en el siglo XIV, donde se celebraron algunos capítulos generales de la Orden. Antes de 1423, el maestre Luis González de Guzmán había reformado la capilla completamente: toda fecha de cal e canto e cubierta de buena madera de pino pintada, lavor muy rica e firme e fermosa, toda fecha de nuevo e muy honrosa para el lugar donde está122. Tal vez próxima a ella estuvieron las crujías de arcos que, respondiendo a los mismos planteamientos estilísticos que la capilla, mandó levantar el citado maestre en torno a un primer patio.

Los maestres Luis de Guzmán ${ }^{123}$ y Pedro Girón acometieron importantes reformas en los dos pisos del segundo patio del complejo maestral, donde destacaban los arcos de herradura realizados en ladrillo. Las armas de estos dos personajes decoraron en número notable el edificio. La parte fundamental de estas reformas estaba acabada para mediados del siglo XV. Finalmente, los dos últimos maestres, Rodrigo Téllez Girón y García López de Padilla, emprendieron nuevas edificaciones, probablemente destinadas a satisfacer necesidades puntuales relacionadas con los servicios palaciegos ${ }^{124}$.

Además importa destacar la labor llevada a cabo por el comendador mayor Gutierre de Padilla. Este relevante freire calatravo mandó levantar un hospital en la villa de Almagro que dotó con una renta muy generosa. Más adelante, en

${ }^{121}$ El edificio de los palacios maestrales, construido con materiales pobres y escasa decoración externa, debió tener sin embargo un fuerte impacto sobre la villa por la extensa superficie que ocupaba. Vid. Villegas Díaz, L.R.: Paisaje urbano con figuras. Almagro, pp. 82-83.

122 AHN, OO.MM.: Visita al Campo de Calatrava, sign. 1412c, fol. 19r.

${ }_{123}$ El profesor Villegas ha planteado la hipótesis de que el maestre Luis de Guzmán realizara una actuación arquitectónica en los palacios hacia la zona de la plaza, con la pretensión de proyectar su imagen -y la de su linaje- hacia un espacio no atendido por sus predecesores y conferir a la plaza un carácter político que no tenía hasta ese momento. Sus sucesores al frente del maestrazgo continuarían con esta misma política. Además este autor indica que la actividad desplegada por los maestres en los palacios tal vez supondría el impulso definitivo para que Almagro se convirtiera en verdadera capital administrativa de la Orden. Vid. Villegas DíAZ, L.R.: Paisaje urbano con figuras. Almagro, pp. 83-88. Ciertamente la hipótesis encajaría bien con el proyecto político de Luis de Guzmán y la proyección simbólica de la «monarquía maestral» que se materializa en las ya comentadas imágenes de la Biblia de Alba. El profesor Villegas piensa que las arquitecturas que contienen las miniaturas de esta obra tienen un contenido simbólico que también se pretendía otorgar a Almagro. En cambio, las cruces negras de la Orden que aparecen en los palacios maestrales no pueden utilizarse como argumento para sustentar la posible realización de obras anteriores a 1397, y concretamente correspondientes al maestre Gonzalo Núñez de Guzmán, como sostiene el citado autor. Las cruces calatravas de color negro siguieron utilizándose con posterioridad a esa fecha como ya indicaba la descripción del convento de Calatrava (COTTA Y MÁRQUEZ DEL PRADO, «Descripción del Sacro Convento y Castillo de Calatrava la Nueva», pp. 44-45) y como puede comprobarse con el análisis visual de los restos heráldicos que figuran todavía en el edificio almagreño, donde las armas de Pedro Girón se alternan con las cruces negras [figura $\mathrm{n}^{\mathrm{o}} 12$ ].

${ }^{124}$ EsPINO NUÑO, «El palacio de los Maestres de la Orden de Calatrava en Almagro en el siglo $\mathrm{XV}$ : nuevos datos documentales acerca de su construcción», pp. 92-99. 
el capítulo de la Orden celebrado en Burgos en 1523, se decidió dedicar una parte de la sustanciosa renta dejada por el comendador Padilla para fundar el monasterio de la Asunción en Almagro, destinado a albergar monjas nobles de la Orden de Calatrava ${ }^{125}$, cuya fábrica material, según el testimonio de mediados del siglo XVII, así de la casa como de la iglesia es, sin exageración, grandiosa y digna de no consentirse al olvido entre los de esta Orden.

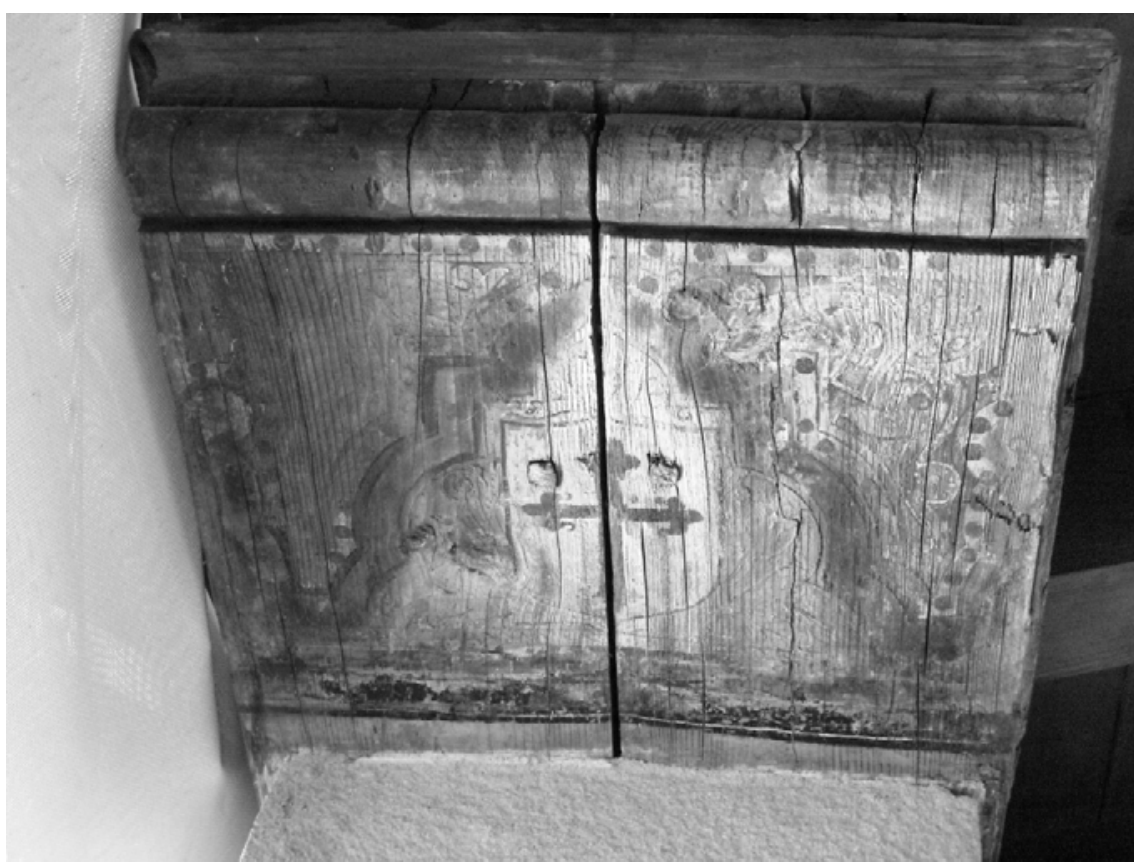

Figura $\mathrm{n}^{\mathrm{O}}$ 12. Escudo con la cruz de Calatrava negra en la planta superior del patio del palacio maestral de Almagro.

Llegados a este punto, conviene preguntarse sobre el papel desempeñado por los freires calatravos en la esfera artística y cultural ${ }^{126}$. El Diccionario de la Lengua Española define la palabra mecenas como "persona que patrocina las letras o las artes» ${ }^{127}$. Bajo este prisma, podemos catalogar de mecenazgo artís-

125 RADES Y ANDRADA, Chronica de Calatrava, fol. 83v.

126 Sobre el arte promocionado por los miembros de las órdenes militares vid. RUIZ MATEOS, A.; PÉrez MonZÓN, O. Y EsPiNO NuÑO, J.: «Las manifestaciones artísticas»: J.M. NieTO SORIA (dir.), Orígenes de la Monarquía Hispánica: Propaganda y legitimación (ca. 1400-1520), Madrid, 1999, 341-368, pp. 349-352; y PÉREZ MONZÓN, «El Arte y las Ordenes Militares», pp. 205-236.

127 Diccionario de la Lengua Española, Real Academia Española, Madrid, 1992, p. 1343. 
tico y cultural el ejercido por los maestres y comendadores mayores calatravos en el último período gótico. Mas en ninguno de los casos comentados, advertimos un apadrinamiento de artistas o un seguimiento de su carrera profesional. Esta dimensión, convertida en un topos común de las cortes europeas renacentistas, es la que expresa el Diccionario de Autoridades al definir el vocablo mecenas como «el príncipe o caballero que favorece, patrocina y premia a los hombres de letras» ${ }^{128}$. Debido a estos matices, algunos autores prefieren hablar en el período bajomedieval de promotores de las artes ${ }^{129}$.

Más allá de la cuestión terminológica, la idiosincrasia de los maestres y comendadores mayores calatravos es la común de la alta nobleza del momento. Las capillas funerarias revelan claramente esa actitud al primar sobre su adscripción calatrava, la fama post mortem y el deseo de glorificar el linaje al que pertenecen ${ }^{130}$. Estos parámetros se manifiestan en todas las órdenes militares como puede comprobarse en los casos de los santiaguistas Lorenzo Suárez de Figueroa ${ }^{131}$, Rodrigo Manrique ${ }^{132}$ o Álvaro de Luna ${ }^{133}$, o en el no menos significativo de Diego de Toledo, en la Orden del Hospital de San Juan de Jerusalén ${ }^{134}$.

En definitiva, podemos afirmar que la nobleza calatrava siguió las mismas pautas que la aristocracia laica en lo que se refiere a mentalidad, ocio, cultura, representación del poder, idea de la fama y perduración post mortem. En estas dos últimas cuestiones los maestres calatravos entraron plenamente en la dinámica nobiliaria de la perpetuación de la memoria del difunto y la exaltación

128 Diccionario de Autoridades, 3 vols.: Madrid, [1732] 1984, III, p. 523.

129 YarZa LuACES, J.: Baja Edad Media. Los siglos del gótico, Madrid, 1992, p. 33.

130 Sobre la mentalidad del momento vid. el clásico libro de LIDA MAIKEL, R.: La idea de la fama en la Edad Media castellana, Madrid, 1983. Un planteamiento general del patrocinio nobiliar en el último período medieval y su trascendencia en el devenir artístico en YARZA LUACES, J.: «Clientes, promotores y mecenas en el arte medieval hispano»: VII Comite Español de Historia del Arte, Murcia, 1988, vol. I, 17-47 y BAYÓN, D.: Mecenazgo y arquitectura en el dominio castellano (1475-1621), Granada, 1991, 27-41.

131 Vid. ANDRÉs ORDAX, S.: «El mecenazgo nobiliar de Extremadura en el siglo XVI y su sensibilidad renacentista»: VII Congreso Español de Historia del Arte, Murcia, 1988, vol. I, 113-122 y Ruiz Mateos, A. y otros, Arte y religiosidad popular. Las ermitas de la Baja Extremadura, Badajoz, 1995 , pp. 41 y 106 y ss.

132 Ruiz Mateos, A. Y Otros, «The Seats of the Priories of the Order of Santiago»: The Military Orders. Fighting for the faith and Caring for the Sick, Londres, 1992, 302-309, pp. 303.

${ }^{133}$ Carrete Parrondo, J.: «Sebastián de Toledo y el sepulcro de don Álvaro de Luna»: Revista de Ideas Estéticas, 131 (1975) 231-237; y YARZA LUACES, «La capilla funeraria hispana en torno a 1400», pp. 67-92. Un análisis global de la personalidad del maestre en FERNÁNDEZ GONZÁLEZ, E.: «Don Álvaro de Luna, condestable de Castilla y maestre de Santiago: hombre de su época y promotor de las artes»: La nobleza peninsular en la Edad Media, León, 1999, 135-170.

134 PÉrez Monzón, O.: «El Patronato artístico de la Orden del Hospital de San Juan de Jerusalén»: Actas de las II Jornadas de la Orden de San Juan, Ciudad Real, 1999, pp. 96-98. 
de su linaje, tal y como demuestran particularmente las capillas funerarias de Gonzalo Núñez de Guzmán y Pedro Girón.

Además, y en relación a las empresas artísticas y culturales desplegadas por los miembros de la nobleza calatrava, es más adecuado referirse a ellos como promotores que como mecenas. Circunstancia que, salvo excepciones puntuales, es extensible también a la aristocracia laica.

Por último, es necesario recordar el ejemplo excepcional que supone las Biblia de Alba como encargo artístico y cultural procedente de la iniciativa de la nobleza calatrava. Sobresale en esta interesante obra la representación de Luis González de Guzmán personificando la «monarquía maestral». Se trata de una obra que supera con creces las pretensiones de la iconografía propia de la aristocracia castellana y sólo puede compararse con la de la realeza. Sin embargo, su valor reside en que no existe tampoco entre las representaciones bajomedievales de los reyes castellanos ninguna que iguale a ésta en la representación rotunda y avasalladora del poder monárquico. 